\title{
Immunotherapy of Malignant Tumors Using Antisense Anti-IGF-I Approach: Case of Glioblastoma
}

\author{
Annabelle Trojan1, Lina M. Jay², Heliodor Kasprzak³, Donald D. Anthony4, \\ Jerzy Trojan ${ }^{2,5^{*}}$ \\ ${ }^{1}$ Faculty of Medicine, CURN University, Cartagena de Indias, Colombia \\ ${ }^{2}$ Department of Investigation, National Institute of Health-INS, Bogota, Colombia \\ ${ }^{3}$ Department of Neurosurgery, CM Nicolas Copernic University, Bydgoszcz, Poland \\ ${ }^{4}$ Department of General Medical Sciences, Case Western Reserve University, Cleveland, USA \\ ${ }^{5}$ INSERM U602, Paul Brousse Hospital, Paris XI University, Villejuif, France \\ Email: "genetherapy@hotmail.fr
}

Received 5 May 2014; revised 3 June 2014; accepted 10 June 2014

Copyright $@ 2014$ by authors and Scientific Research Publishing Inc.

This work is licensed under the Creative Commons Attribution International License (CC BY). http://creativecommons.org/licenses/by/4.0/

\section{(c) (i) Open Access}

\section{Abstract}

The review article describes the criteria established for methodology of antisense anti IGF-I therapy of malignant tumors, particularly of glioblastoma. The cancer patients, after classical therapy of surgery, radiotherapy and chemotherapy, have undergone the injection of genetically modified autologous malignant cells - transfected by IGF-I antisense/triple helix expression vectors. For all cancer patients supervised for up to 19 months, the period corresponding to minimum survival of glioblastoma patients, the following common immune criteria for "anti IGF-I" strategy were admitted: 1) characteristics of cell "vaccines"-absence of IGF-I and expression of MHC-I in cloned transfected cells; 2) the peripheral blood lymphocytes, PBL cells, removed after every of two successive vaccinations, demonstrate an increasing level of $\mathrm{CD8}^{+}$and $\mathrm{CDB}^{+} 28^{+}$molecules (with a switch from $\mathrm{CDB}^{+} \mathbf{1 1 b ^ { + }}$ to $\mathrm{CDB}^{+}+11 \mathrm{~b}^{-}$).

\section{Keywords}

Immunogene Therapy, Malignant Tumors, Glioblastoma, IGF-I, Antisense

\footnotetext{
${ }^{*}$ Corresponding author.
}

How to cite this paper: Trojan, A., Jay, L.M., Kasprzak, H., Anthony, D.D. and Trojan, J. (2014) Immunotherapy of Malignant Tumors Using Antisense Anti-IGF-I Approach: Case of Glioblastoma. Journal of Cancer Therapy, 5, 685-705. 


\section{Introduction}

\subsection{Immune Aspect in Antisense Strategy}

The efficiency of antisense strategy in experimental and clinical therapies [1] [2] was demonstrated for the first time, both in vitro and in vivo using rat glioma model and episomal pMT/Ep vector [3]. Such strategy of antigene type (antisense or triple helix, AS or TH) [4]-[6] has permitted to stop the development of established animal tumors of glioma, hepatoma, melanoma and teratocarcinoma (containing three tissue derivatives) as well as of human gliomas, mediated by immune anti-tumor $\mathrm{CD}^{+} \mathrm{T}$ cells induced in vivo by injection of cellular "vaccines" presenting immunogenic character (expression of MHC-I) [7]-[10]. We have previously described the immune cellular/anti-gene anti IGF-I approach [7] targeting IGF-I, the growth factor playing a principal role in the tumor growth processes [11]-[14]. The goal of this review was to describe how the immune criteria of antigene IGF-I methodology for clinical trial were established (Phase I gene therapy of glioblastoma). These criteria were based on principal results of the described experimental and clinical studies-the immune anti-tumor phenomena observed in the antisense anti IGF-I treatment of rat and human gliomas, and signaled by the increase of CTL CD8 ${ }^{+}$in the animal and human tumor tissues, and confirmed in human peripheral blood lymphocytes [7].

The cytotoxic $\mathrm{T} \mathrm{CD8}{ }^{+}$cell can exert its effect if a bridge between CD8 and the antigen of class I major histocompatibility complex (MHC) occurs [15]-[19]. Following transfection of glial cells with the antisense cDNA of IGF-I, the expression of MHC-I in transfected glioma cells in vitro, is greatly enhanced (5 times). This mechanism may play a role in the cytotoxic response, although not the only one involved [20]. In preclinical experiments, the bearing tumor rats receiving injections of transfected cells have revealed a very high rate of CD8 ${ }^{+}$ cells. This anti-tumor immune response has stopped the tumor development [3] [21]-[24]. In the presented work, we have used the strategy of combined antisense/triple helix technologies to prepare the anti-gene anti IGF-I "vaccines" and investigate an immune response in treated patients with malignant tumors expressing IGF-I. Comparatively, the tumors representing three tissue derivatives were considered: principally neuroectodermalglioblastoma, and also entodermal—colon cancer, and mesodermal—cancers of ovary and of prostate.

\subsection{Anti-Gene Strategies: Antisense and Triple Helix}

Since 1978 it is known that antisense messengers are naturally produced and destroyed in the process of DNA replication [4] [25]-[28]. The authors successfully demonstrated that this phenomenon is possible in twenty different species. It is possible for the researchers to produce artificial antisense messengers in significant amount [28]-[30]. Moreover, when using antisense oligonucleotides associated with the photo luminescent amino-terminated poly amido amine dendrimer, they can be directly analyzed by fluorescence microscopy and flow cytometry [31]. The antisense sequences are capable of blocking the messenger RNA translation conducting to block of specific protein synthesis. The antisense approach has now been introduced in cancer gene therapy as well experimental as clinical trial, principally in gliomas treatment (Table 1).

Since the 1990's, another approach in parallel with the strategy of antisense RNA has become successful in gene therapy and clinical trials: the triple helix strategy (TH) [32]-[34]. The technology was discovered by P.B. Derwan and C. Helene [5] [6], and its action was defined as inhibition of gene expression at the level of transcription. In short, specific oligonucleotide sequences (also called triple helix-forming oligonucleotides, TFOs) are introduced into cells by transfection using chemical carriers, such as plasmid vectors which can direct synthesis TFOs. The TFOs are linked to the genomic DNA forming the triple helix structure with the target gene and inhibiting its transcription. The TFOs usually are directed against sequences located in the promoter region of genes of interest [5]. Examples of the inhibitory activity of TFOs on target genes involved in tumorigenesis are currently available [35]-[37]. Moreover, synthesis of Human Tumor Necrosis Factor (TNF), and which acts as an autocrine growth factor in various tumor cell lines including neuroblastoma and glioblastoma has been blocked by treatment with TFOs [38].

\section{Methodology}

\subsection{Preparation of "Vaccines"}

\subsubsection{Plasmids}

IGF-I AS and TH technologies were used to construct episome based plasmids either pMT-Anti-IGF-I expressing IGF-I RNA antisense, or pMT-AG inducing the IGF-I RNA-DNA triple helix, coming from pMT-EP "emp- 
Table 1. Examples of experimental and clinical gene therapies of gliomas using antisense approach: articles since 2000's (technology antisense, AS; technology triple-helix, TH).

\begin{tabular}{|c|c|c|}
\hline Target & Strategy & References \\
\hline IGF-I & AS \& TH vectors, experimental therapy & Ly et al. (2001) Mol Pathol 54:230 \\
\hline IGF-I-R & AS oligodeoxynucleotide, clinical trial & Andrews et al. (2001) J Clin Oncol 19:2189 \\
\hline c-myb & AS oligodeoxynucleotide, experimental therapy & Hu et al. (2001) Hua XI Yi 32:562 \\
\hline VEGF & AS vector, experimental therapy & Zhang et al. (2002) Zhonghua Yi 80:386 \\
\hline EGF-R & AS vector, experimental therapy & Zhang et al. (2002) J Gene Med 4:183 \\
\hline c-myb & AS oligodeoxynucleotide, experimental therapy & Zhao et al. (2002) Hua XI Yi 33:19 \\
\hline IGF-I & AS \& TH vectors, clinical trial & Trojan et al. (2003) Roc Akad Med Biol 48:18 \\
\hline Bcl-2 & AS oligodeoxynucleotide, experimental therapy & Zhu et al. (2003) J Neurosci Res 74:60 \\
\hline Laminin-8 & AS oligodeoxynucleotide, experimental therapy & Khazenzon et al. (2003) Mol Cancer Ther 2:985 \\
\hline $\begin{array}{l}\text { Urokinase plasmin } \\
\text { activator }\end{array}$ & AS vector, experimental therapy & Gondi et al. (2003) Oncogene 22:5967 \\
\hline $\begin{array}{l}\text { TGF-beta, FGF and } \\
\text { VEGF }\end{array}$ & $\begin{array}{l}\text { AS oligodeoxynucleotide and vector, exp. } \\
\text { therapy }\end{array}$ & Matsumo \& Nagashima (2004) Med Electron Microsc 37:158 \\
\hline AKT2 & AS vector, experimental therapy & Pu et al. (2004) Tumor Biol 25:172 \\
\hline TGF-beta2 & AS oligodeoxynucleotide (AP 12009), exp. therapy & Schligensiepen et al. (2005) Oligonucleotides 15:94 \\
\hline PKC-alpha & $\begin{array}{l}\text { AS oligodeoxynucleotide (aprinocarsen), } \\
\text { clinical trial }\end{array}$ & Grossman et al. (2005) Neurol Oncol 7:32 \\
\hline TGF-beta2 & $\begin{array}{l}\text { AS oligodeoxynucleotide (AP 12009), exp. ther., } \\
\text { clin. trial }\end{array}$ & Schlingensiepen et al. (2006) Cytok Growth Factor Rev 17:129 \\
\hline Laminin-8 & AS oligodeoxynucleotide, experimental therapy & Fujita et al. (2006) Angiogenesis 9(4):183 \\
\hline $\begin{array}{l}\text { FAC (focal adhesive } \\
\text { kinase) }\end{array}$ & AS oligodeoxynucleotide, experimental therapy & Wu et al. (2006) J Neuro Oncol 27(2):117 \\
\hline $\begin{array}{l}\text { Galactosyl- } \\
\text { transferase (4GalTV) }\end{array}$ & AS vector, experimental therapy & Jiang et al. (2006) Glycobiol 16(11):1045 \\
\hline PI3K regulated-ILK & AS oligodeoxynucleotide, experimental therapy & Edwards et al. (2006) Mol Cancer Ther 5(3):645 \\
\hline AKT2 & AS vector, experimental therapy & Pu et al. (2006) J Neuro Oncol 76(1):1 \\
\hline VEGF & AS oligodeoxynucleotide, experimental therapy & Hong et al. (2006) Cancer Letters 2361:39 \\
\hline EGF-R & AS vector, experimental therapy & Kang et al. (2006) Cancer Gene Ther 13:530 \\
\hline EGF-R and PTEN & AS vector, experimental therapy & Tian et al. (2006) Neuropath 26(3):178 \\
\hline $\begin{array}{l}\text { cMET (receptor } \\
\text { tyrosine kinase) }\end{array}$ & AS oligodeoxynucleotide, experimental therapy & Chou et al. (2006) Surg Neuro 65(6):533 \\
\hline TGF beta 2 & AS vector, clinical trial & Fakhrai et al. (2006) Cancer Gene Ther 13:1052 \\
\hline IGF-I & AS \& TH vectors, clinical trial & Kasprzak et al. (2006) Neurol Neurochir 40(6):509 \\
\hline IGF-I & AS \& TH vectors, clinical trial & Trojan et al. (2007) Int J Cancer Prev 2(4):227 \\
\hline IGF-I, IGF-I-R & $\begin{array}{l}\text { AS \&TH vectors, experimental therapy and } \\
\text { clinical trial }\end{array}$ & Trojan et al. (2007) Neuroscience 145:795 \\
\hline TGF-beta 2 & AS oligodeoxynucleotide (AP 12009) clinical trial & Hau et al. (2007) Oligonucleotides 17(2):201 \\
\hline $\begin{array}{l}\text { Glycogen synthase } \\
\text { (GS) }\end{array}$ & AS vector, experimental therapy & Ardourel et al. (2007) Cancer Biol Ther 6(5):719 \\
\hline Telomerase (hTERT) & AS adenoviruse, experimental therapy & You et al. (2007) Cell Mol Life Sci 64(5):621 \\
\hline Telomerase & AS oligonucleotide (2-5A-anti-hTR), exp. therapy & Iwado et al. (2007) Int J Oncol 31(5):1087 \\
\hline $\begin{array}{l}\text { XIAP (inhibitor } \\
\text { of apoptosis) }\end{array}$ & AS adenovirus, experimental therapy & Naumann et al. (2007) Gene Ther 14(2):147 \\
\hline $\begin{array}{l}\text { c-Met (receptor } \\
\text { tyrosin kinase) }\end{array}$ & AS oligonucleotide, experimental therapy & Chu et al. (2007) J Surg Res 141(2):284 \\
\hline Urokinase (uPAR) & AS vector, experimental therapy & Nabothula et al. (2007) Int J Oncol 30(3):669 \\
\hline
\end{tabular}




\section{Continued}

\begin{tabular}{|c|c|c|}
\hline $\begin{array}{l}\text { Laminin \& Tf and } \\
\text { 2C5 antibod. }\end{array}$ & AS oligonucleotide, experimental therapy & Fujita et al. (2007) J Control Release 122(3):356 \\
\hline Caspases 3 \& 8 & AS oligonucleotide, experimental therapy & Gdynia et al. (2007) Mol Cancer Res 5(12):20 \\
\hline miR-21 & AS oligonucleotide, experimental therapy & Gabriely et al. (2008) Mol Cell Biol 28(17):536 \\
\hline $\operatorname{miR}-21$ & AS oligonucleotide, experimental therapy & Shi et al. (2008) Zhonghua Yi 25(5):497 \\
\hline $\begin{array}{l}\text { TGF-beta and } \\
\text { immune activation }\end{array}$ & AS oligonucleotide (NPs), experimental therapy & Schneider et al. (2008) J Neuroimmun 195(1-2):21 \\
\hline $\begin{array}{l}\text { TGF-beta and } \\
\text { immune activation }\end{array}$ & AS oligonucleotide, experimental therapy & Vega et al. (2008) Future Oncol 4(3):433 \\
\hline $\begin{array}{l}\text { Heat shock-protein } 27 \\
\text { (Hsp27) }\end{array}$ & AS oligonucleotide, experimental therapy & Aloy et al. (2008) Int J Radiat Oncol Biol Phys 70(2):543 \\
\hline VEGF & AS vector, experimental therapy & Lin et al. (2008) Cancer Sci 99(12):2540 \\
\hline TGF-beta 2 & AS oligodeoxynucleotide, clinical trial & Schlingensiepen et al. (2008) Rec Res Cancer Res 177:137 \\
\hline IGF-I & AS vector, clinical trial & Trojan et al. (2009) JAC 1:1 \\
\hline TGF-beta 2 & AS oligodeoxynucleotide, clinical trial & Hau et al. (2009) Expert Rev Anticancer Ther 9(11):166 \\
\hline IGF BP2 & AS vector, experimental therapy & Moore et al. (2009) Proc Natl Acad Sci USA 106(39):16675 \\
\hline CD133/ & AS oligonucleotide, experimental therapy & Yao et al. (2009) Oncol Rep 22(4):781 prominin-1 \\
\hline EGFR & AS oligonucleotide, experimental therapy & Loew et al. Anticancrer Agents Med Chem 9(6):703 \\
\hline TGF-beta & AS oligodeoxynucleotide, clinical trial & Vallieres (2009) IDrugs 12(7):445 \\
\hline miR-21 & AS oligonucleotide, experimental therapy & Li et al. (2009) Brain Res 25(1286):13 \\
\hline $\operatorname{miR} 221 / 222$ & AS oligonucleotide, experimental therapy & Zhang et al. (2009) Int J Oncol 34(6):1653 \\
\hline IGF-I & AS vector, clinical trial & Trojan et al. (2010) Biomed \& Pharmaother 64(8):57 \\
\hline miR-21 & AS oligonucleotide, experimental therapy & Zhou et al. (2010) Oncol Rep 24(1):195 \\
\hline c-Met & AS oligonucleotide, experimental therapy & Chu et al. (2010) Oncol Rep 24(1):189 \\
\hline AKT2 & AS oligonucleotide, experimental therapy & Zhang et al. (2010) Oncol Rep 24(1):65 \\
\hline EGFR & AS oligonucleotide, experimental therapy & Li et al. (2010) Oncol Rep 23(6):1585 \\
\hline $\begin{array}{c}\text { PED/PEA-15 } \\
\text { (ERK1/2-inter. } \\
\text { protein) }\end{array}$ & AS oligonucleotide, experimental therapy & Botta et al. (2010) Hum Gene Ther 21(9):1067 \\
\hline miR-21 \& 5FU & AS oligonucleotide, experimental therapy & Ren et al. (2010) J Biomater Sci Polym Ed 21(3):303 \\
\hline $\operatorname{miR}-21$ & AS oligonucleotide, experimental therapy & Zhou et al. (2010) Lab Invest 90(2):144 \\
\hline EGFR & AS oligonucleotide, experimental therapy & Kang et al. (2010) J Biomed Mater Res A 93(2):585 \\
\hline Laminin-411 & AS oligodeoxynucleotide, clinical trial & Ding et al. (2010) Proc Natl Acad Sci USA 107(42):18143 \\
\hline $\begin{array}{l}\text { TGF-beta \& T cell } \\
\text { therapy }\end{array}$ & AS oligodeoxynucleotide, clinical trial & Dietrich et al. (2010) Curr Opin Oncol 2010; 22(6):604 \\
\hline Telomerase \& taxifen & AS oligonucleotide, experimental therapy & Wang et al. (2010) Mol Med Report 3(6):935 \\
\hline VEGF & AS vector, experimental therapy & Yang et al. (2011) J Neurooncol 103(1):33 \\
\hline IGF-I & AS vector, clinical trial & Trojan \& Anthony (2011) Curr Signal Transd Ther 6(3):411 \\
\hline TGF-beta & AS oligodeoxynucleotide, clinical trial & Jashinsky et al. (2011) Curr Pharm Biotechnol 12(12):220 \\
\hline TGF-beta & AS oligodeoxynucleotide, clinical trial & Hau et al. (2011) Curr Pharm Biotechnol 12(12):2250 \\
\hline $\operatorname{PrPc}$ & AS oligonucleotide, experimental therapy & Barbieri et al. (2011) Autophagy 2011 Aug 1; 7(8). [Epub] \\
\hline $\operatorname{miR}-10 b$ & AS oligonucleotide, experimental therapy & Sun et al. (2011) Brain Res 1389:9 \\
\hline uPAR & AS vector, experimental therapy & Raghu et al. (2011) Mol Cancer 10:130 \\
\hline microRNA-7 & AS oligonucleotide, experimental therapy & Lee et al. (2011) Radiother Oncol 101(1):171 \\
\hline miR-221/222 & AS oligonucleotide, experimental therapy & Hao et al. (2012) Oncol Rep 27(5):1504 \\
\hline
\end{tabular}




\begin{tabular}{|c|c|c|}
\hline Cont & & \\
\hline $\begin{array}{c}\text { miR-143 and } \\
\text { miR-145 }\end{array}$ & AS oligonucleotide, experimental therapy & Koo et al. (2012) BMC Cancer 12:143 \\
\hline miR-1275 & AS oligonucleotide, experimental therapy & Katsushima et al. (2012) J Biol Chem 2012 Jun 26 [Epub] \\
\hline PTBP1 & AS oligonucleotide, experimental therapy & Izaquirre et al. (2012) Mol Carcinog 51(11):895 \\
\hline miR-21 & AS oligonucleotide, experimental therapy & Zhou et al. (2012) Zhonqhua Znonq Liu Za Zhi 33(10):74 \\
\hline ATM & AS vector, experimental therapy & Chuah et al. (2012) Int J Oncol 40(6):1963 \\
\hline miR-143 \&-145 & AS vector, experimental therapy & Koo et al. (2012) BMC Cancer 12:143 \\
\hline 18-kDa-TSPO & AS vector, experimental therapy & Veenman et al. (2012) Pharmacogenet Genomics 22(8):606 \\
\hline miR-1275 & AS oligonucleotide, experimental therapy & Katsushima et al. (2012) J Biol Chem 287(33):27396 \\
\hline miR-21 & AS oligonucleotide, experimental therapy & Wong et al. (2012) Anticancer Res 32(7):2835 \\
\hline Metallo-thionein $1 \mathrm{E}$ & AS vector, experimental therapy & Ryu et al. (2012) Int J Oncol 41(4):1305 \\
\hline miR-92a & AS oligonucleotide, experimental therapy & Niu et al. (2012) Oncol Rep 28(5):1771 \\
\hline 14-3-3-beta & AS vector, experimental therapy & Park et al. (2012) Neurol Res 34(9):893 \\
\hline MMP-9 & AS vector, experimental therapy & Sun et al. (2013) 29(1):83 \\
\hline miR106b & AS oligonucleotide, experimental therapy & Zhang et al. (2013) J Neuro-oncol 112(2):179 \\
\hline miR-30a-5p & AS oligonucleotide, experimental therapy & Jia et al. (2013) PLoS One 8(1):e55008 \\
\hline IGF-I & AS vector, experimental therapy & Pan et al. (2013) PLoS One 8(3):e58428 \\
\hline EGF-R & AS vector, experimental therapy & Kalman et al. (2013) Neuromolecular Med 15(2):420 \\
\hline miR-21 & AS oligonucleotide, experimental therapy & Costa et al. (2013) Mol Ther Nucleic Acids 2:e100. \\
\hline
\end{tabular}

ty" vector [3] [37]. The cassette contains the Epstein-BarrVirus origin of replication and the gene encoding nuclear antigen I, which together drive extrachromosomal replication. (This type of vector based on EBV elementsconfer higher transgene expression in primary human tumors [39]). In the pMT-AG triple helix, the cassette consists of a 23 bp DNA fragment cloned into the pMT-EP vector, which transcribes a third RNA strand forming a triple helix structure within the target region of the human IGF-I gene (Figure 1). The triple helix structure forming IGF-I RNA-DNA structure, giving rise to used IGF-I triple helix gene therapy approach, was largely described in previously published papers; moreover, the experimental data in vitro accompanied by control experiments constituted by use of either antisense technique or by use of control "empty" vectors were also performed [24] [37]. The vector and the cells transfected with these vectors (see below) were tested for the presence of DNA sequence of EBV virus-in the vector, the $4.4 \mathrm{~Kb}$ sequence of EBV is inserted. The tests of PCR EBV have given the negative results (Texcell-Institut Pasteur, ref. 114/01/1054D-02/07 and -01/03; report 27.03.1996). Although the tests date back from 1996, the results are still valid as the total sequence of used vectors were never changed.

\subsubsection{Primary Parental and Transfected Cell Cultures}

Surgically removed biopsies of primary malignant tumors as follows: glioblastoma (astrocytoma grade IV, glioblastoma multiforme), colon carcinoma (differenciated adenocarcinoma), ovary carcinoma (cystadeno-carcinoma) and prostate carcinoma (adenocarcinoma, cytologic malignancy, grade I) were used to establish primary cell cultures. Two cases of each malignant tumor were investigated. Surgical resections were done in the University Hospital of Bromberg (Bydgoszcz), Poland, and in National Institute of Cancerology in collaboration with INS, Bogota. Primary cell lines originated from every biopsy were established during 3 - 4 weeks [24] simultaneously in three countries (Bromberg and Cracow, Poland, Paris, France, and Bogota, Colombia).

Cells were cultured in DMEM (GIBCO-BRL) supplemented with 10\% FCS, $2 \mathrm{mM}$ glutamine, $100 \mathrm{U} / \mathrm{ml}$ penicillin and $100 \mu \mathrm{g} / \mathrm{ml}$ streptomycin, at $37^{\circ} \mathrm{C}$ and $5 \% \mathrm{CO}_{2}$ (Figure 2). In the case of glioblastoma and colon cancer, primary human cell lines established previously (CWRU, Cleveland, and Paul Brousse Hospital, Villejuif) have played a role of "cell line controls" for verifications of IGF-I presence (immunocytochemical reaction for IGF-I, using antibodies anti IGF-I, and confirmed by RT-PCR), and MHC-I and B7 antigens absence (immunocytochemical or flow cytometry analysis using antibodies anti MHC-I and anti B7) [23] [24] [40] [41]. 


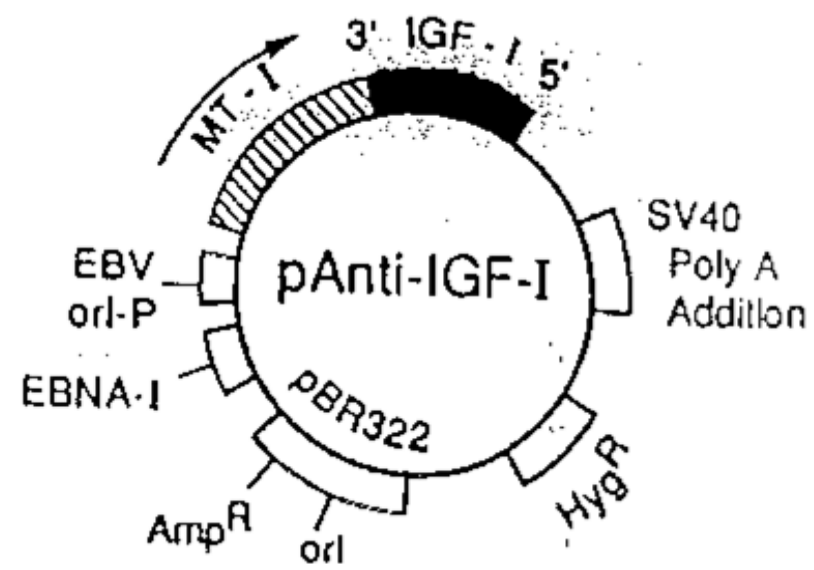

Figure 1. Vector encoding IGF-I cDNA in antisense orientation. Episome based plasmid (pMT-Anti-IGF-I) expressing IGF-I RNA antisense coming from pMT-EP “empty”). vector [3] (see Methodology The cassette contains the Epstein-Barr Virus origin of replication and the gene encoding nuclear antigen I, which together drive extrachromosomal replication.

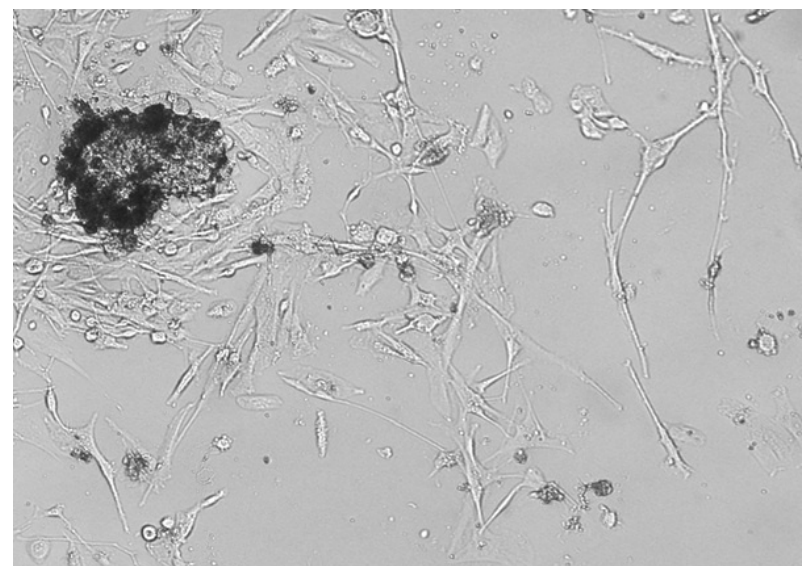

Figure 2. In vitro culture of primary human malignant cells derived from surgical biopsy of glioblastoma. Parental tumour cells, proliferating from the tissue of biopsy (note dark black cluster-left up), are attached efficiently after two weeks of primary culture $[\times 200]$.

RT-PCR technique was applied as described earlier [42]. RNA from cells was isolated using High Pure RNA Isolation Kit (Roche Diagnostics GmbH n ${ }^{\circ}$ 1828665. The applied components of RT PCR were used according Reverse Transcription System Promega Corporation ( $\mathrm{n}^{\circ}$ A3500. The following primers were used for RT PCR study of human IGF-I:

Forward primer IGF-I: GCATCTCTTCTACCTGGCGCTG, and

Reverse primer IGF-I: caggcttgaggggtgcgcaata (sequence according “rgd” Human Genome Database).

In addition, the quality control of the tumor cultured cells has concerned the test for mycoplasma, endotoxin and aerobic and anaerobic bacteria.

Total transfection of cell cultures was obtained after 2 - 3 weeks, using AS and TH vectors, by either $\mathrm{Ca}^{++} / \mathrm{Ph}^{2}$ technique or FuGENE 6 Transfection Reagent (Boehringer Mannheim). 48 hours after applied FuGENE techbniquet, the selection of transfected cells was done in the presence of Hygromycin B (Boehringer Mannheim) at a concentration of $0.005 \mathrm{mg} / \mathrm{ml}$. After one week, concentration of hygromycin B was changed to $0.015 \mathrm{mg} / \mathrm{ml}$, and progressively increased up to $0.15 \mathrm{mg} / \mathrm{ml}$ and maintained with each change of fresh medium over the next 2 - 3 months. Two weeks after application of FuGENE, cell lines derived of the same tumor, were verified for ab- 
sence of IGF-I using immunocytochemistry technique, confirmed by RT PCR technique [42] [43] (Figure 3), and for presence of MHC-I and B7 molecules using flow cytometry analysis (Figure 4): monoclonal antibodies, labeling human MHC-I (HLA), MHC-II, CD80 and CD86 (B7) antigens were used for direct immunostaining (Becton Dickinson Pharmingen) [40]. The expression of IGF-I, MHC-I and B7 in non transfected and transfected separately "antisense" and "triple helix" cancer cell lines, was verified in the laboratories of Bromberg and Krakow (Poland), Cleveland (USA), Villejuif (France) and Bogota (Colombia). The cell lines transfected with "empty" vector have constituted a negative control for both "antisense" and "triple helix" lines.

AS and TH cell clones expressing MHC-I and B7 molecules were used for preparation of cell vaccines (in general, $40 \%$ - 50\% of clones were positively stained for MHC-I, and $50 \%-60 \%$ of clones were negative for MHC-I). The cultures of these clones, four weeks after transfection have presented about $50 \%-60 \%$ of apoptotic cells, and $40 \%-50 \%$ of no apoptotic cells which were IGF-I (-), MHC (+) and B7 (+). The MHC-I and B7 expression, as well as apoptosis were verified as described earlier [8] [43] (Figure 4).

The established cell cultures were divided in three parts. The first part, 200,000 cells, was used for the preparation of cell membranes, prepared according to the technique of Matlib [44]. These cell membranes have constituted the material for first, non-cell, "membrane vaccination". When the cells growing in culture were numerous enough, 3 - 5 million "antisense cells" and "triple helix cells", respectively, one part of them was used for "cellular vaccination"-injection of 3 million of cells: 1.5 million of "antisense cells" mixed with 1.5 million "triple helix cells", and another part was frozen as "back-up" in liquid nitrogen.

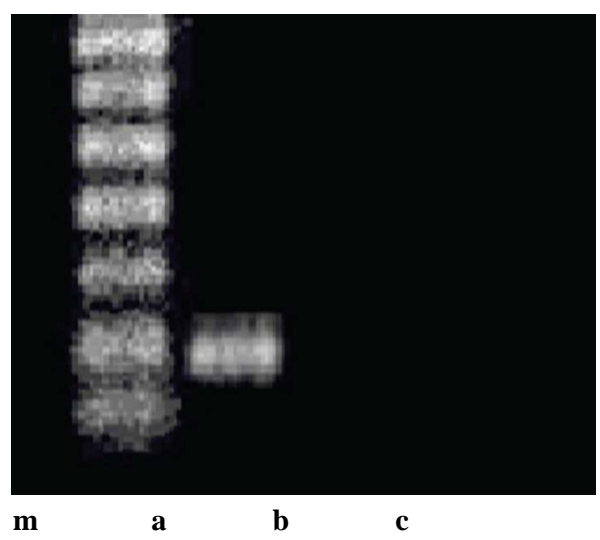

Figure 3. Expression of IGF-I in primary human glioma cell lines, parental and transfected cells. RT PCR technique. M: marker (down/up: from $100 \mathrm{bp}$ to $700 \mathrm{bp}$ band). a: presence of IGF-I in parental cells (200 bp band of amplified DNA using IGF-I primer). b: absence of IGF-I expression in cells transfected with antisense anti IGF-I vector. c: absence of IGF-I expression in cells transfected with triple helix anti IGF-I vector.
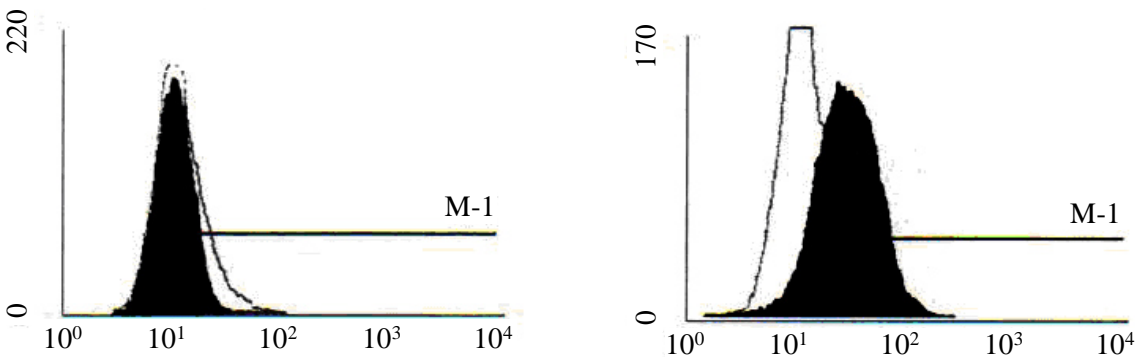

Figure 4. Expression of MHC-I in an established primary human glioma cell line. Flow cytometry analysis (FACScan Becton Dickinson). Panel left: parental non transfected cells. Panel right: cells transfected with both antisense and triple helix anti IGF-I vectors. 


\subsection{Vaccination of Cancer Patients}

Six patients in University Hospital of Bydgoszcz and six patients in CWRU Hospital of Cleveland, were treated for glioblastoma, respectively. The patients in Bydgoszcz were divided in three groups of two cases each (considering that this clinical trial was the beginning of Phase 1 presenting a limited number of patients, the statistical analysis was not included in the study). In every group the age of patients were about twenty years and sixty years, respectively (the individual characteristics are not a subject of the presented work). In the first group, the patients treated by surgery, radiotherapy and chemotherapy (low dose chemotherapy-temozolomide $75 \mathrm{mg} / \mathrm{m}^{2}$ / day, applied during the period of radiotherapy) have followed three successive subcutaneous injections of cellular membranes isolated from IGF-I antisense/triple helix transfected cells ("membrane vaccinations"). In the second group after surgery, radiotherapy and chemotherapy (low dose), the first membrane injection was followed by two successive subcutaneous "cellular vaccinations" composed of IGF-I AS/TH cells containing both apoptotic and no apoptotic cells. The third group, a control group, was treated by surgery, radiotherapy and chemotherapy.

On the other side, six glioblastoma patients in Cleveland were treated by unique therapy: surgery, radiotherapy and chemotherapy was followed by successive subcutaneous "cellular vaccinations" composed of IGF-I AS cells containing both apoptotic and no apoptotic cells. In parallel, the patients with cancers of colon, ovary and prostate (Bydgoszcz) have followed the treatment composed of surgery, radiotherapy and successive "cellular vaccinations" (see Section 3.3).

The injections were done with interval of four - five weeks. 48 hours before every vaccination, the membrane or cell pellets ("membrane” or "cellular" therapies) were irradiated with 5000 Gy gamma (Co60 or Cs137) [40]. The membranes or cells were injected subcutaneously, into the left arm of operated cancer patients, in $1 \mathrm{ml}$ of PBS solution. The blood was collected three times: before vaccinations and after every of two cell vaccinations ( 2 - 3 weeks after the second and the third injection). Flow cytometric analysis of PBL cells was done as follows; Peripheral blood lymphocyte (PBL) typing was performed after hemolysis by incubation of peripheral blood with monoclonal antibodies against the cell antigens: CD3, CD4, CD5, CD8, CD8 ${ }^{+} 11 \mathrm{~b}^{+}, \mathrm{CD}^{+} 11 \mathrm{~b}^{-}, \mathrm{CD}^{+} 28^{+}$, CD19, CD3- $\left(16^{+} 56\right)^{+}(\mathrm{NK})$, CD25, CD44, CD45 (Becton Dickinson Pharmingen, direct immunstaining). Paraformaldehyde-fixed cells were examined in FACSscan BD cytometer. Double direct immunotyping with pairs of monoclonal antibodies conjugated with FITC and PE were used. Lymphocyte gate was defined according to the CD45 back gating. Data were presented as percentage of positive cells [42]. The PBL labelling of cells was done simultaneously in two laboratories (Bydgoszcz and Villejuif).

\section{Results}

Each primary cell line was subcloned to obtain IGF-I positive clones (the percent of IGF-I positive cells in the human cell lines ranged from $50 \%$ to $70 \%$ ). All the primary cells lines were also transfected, showing a change of phenotype. The examples of primary cell lines as well as of transfected cell lines of ovary and prostate cancers are shown in Figure 5.

Using RT PCR, analysis of RNA of cancer cells four weeks after transfection was compared to RNA of parental cells. Then the transfected cells (not expressing IGF-I), serving as "vaccines" for different types of cancers were cloned to obtain MHC-I postive cell lines. The transfected MHC-I postive cancers cells have also expressed B7 antigen with exception of hepatoma transfected cells as described earlier [8]. Human cancer cells transfected with "empty" vector, pMT/EP, serving as negative control, were stained positively for IGF-I and negatively for MHC-I and B.

In treated patients, with higher mentioned "vaccines", the typing of PBL cells removed from blood samples was performed. Clear-cut phenotypic changes in peripheral blood lymphocytes (PBL) was observed in all cancer diseases treated with "cellular therapy": after the first cell vaccination, the increase of CTL CD8 ${ }^{+}$, particularly $\mathrm{CD}^{+} 11 \mathrm{~b}^{-}$, was observed. There was a characteristic switching from $\mathrm{CD}^{+} 11 \mathrm{~b}^{+}$to $\mathrm{CD} 8^{+} 11 \mathrm{~b}^{-}$which was practically not significant in the group of "membrane therapy" applied for two glioblastoma patients. This increasing switching was also observed after the second cell vaccination in all treated cancers. Moreover, the PBL cells have demonstrated, in all types of tumor diseases, an increasing expression of cell surface markers $\mathrm{CD} 8^{+} \mathrm{CD} 28^{+}$ confirming the effectiveness of "cellular therapy" (Figures 6(A)-(D)).

The specificity of immune response was every time confirmed as follows. As demanded by approved clinical trials (see Section 4-Ethical Consideration), the removed PBL of patients were tested in vitro for immune 

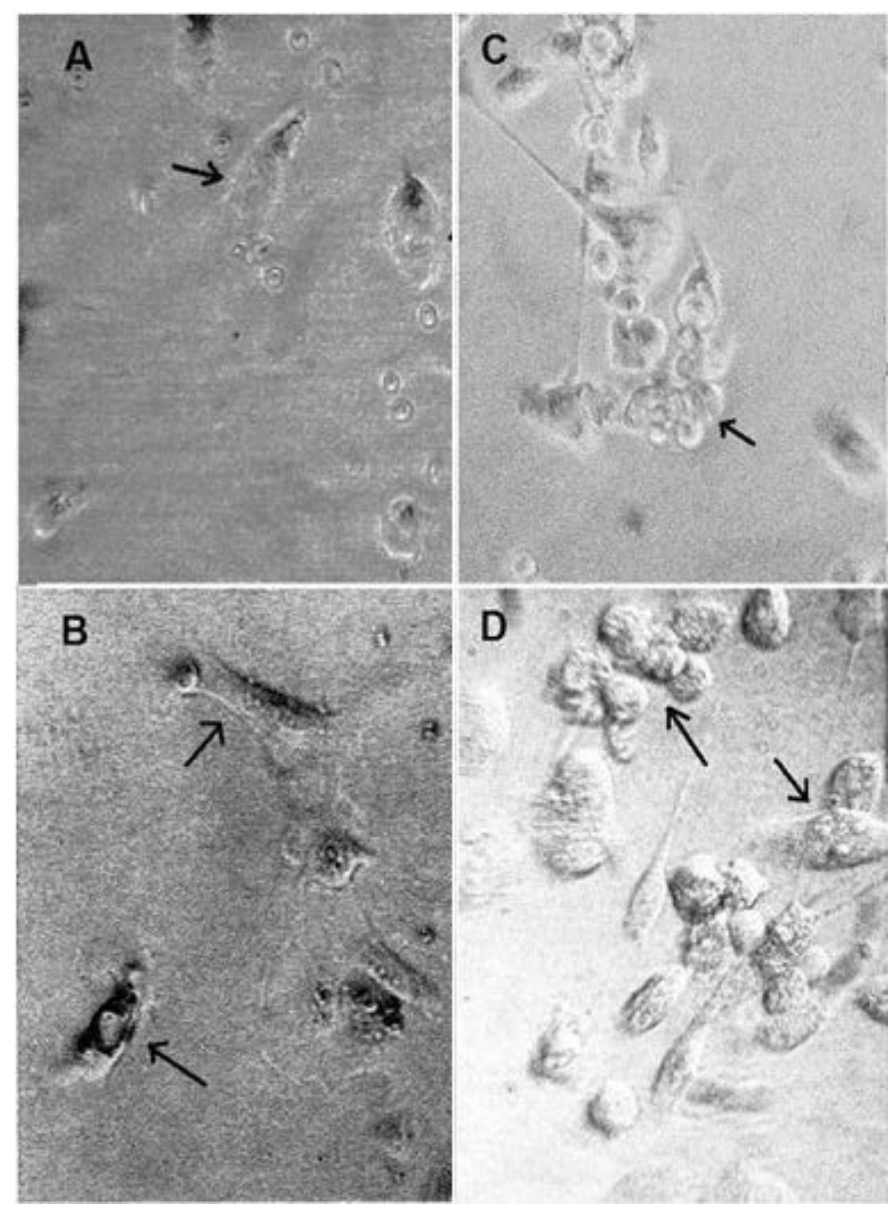

Figure 5. Examples of in vitro culture of primary human cancer cells derived from surgical biopsies. Panel (A) and (C) - primary ovary cyst-adenocarcinoma derived cells. Panel (B) and (D) - primary prostate adenocarcinoma derived cells. Parental ovary cancer cells (A) and prostate cancer cells (B) are attached efficiently in the fourth day of culture (arrows). "Antisense/triple helix" anti-IGF-I ovary cancer cells (C), and prostate cancer cells (D), both twenty days after transfection, form the established lines characterized often by the clusters of round apoptotic cells, becoming progressively small ((C), arrow; (D), arrow up). They are accompanied by no apoptotic and more voluminous cells ((D), arrow down) presenting generally elongated shape ((C) and (D)). The transfected cells are always different from non transfected parental cells ((A), (B)), as it was demonstrated previously in cases of human glioma and hepatoma cell lines established from primary tumours of glioblastoma and hepatocarcinoma [20] [23] [24], ×400.

response after contact with autologous tumor cells to demonstrate antitumor activation through high percentage of specific $\mathrm{T}$ cells observed after vaccination compared to controls-before vaccination (the tumor cells were labeled with Cr51 before the test of lyses in the presence of CTL cells [45] [46]; data not shown). Other examined CD molecules as CD3 or CD19, CD45 (data not shown) were not shown the significant values in all treated cancers. In the case of CD4, slightly decreased values were registered (as only two cases of each tumor were studied, these observations not be statistically valuable). That is important to add that no significant change in CTL CD8 level was observed before and after the surgery, and before and after radiotherapy treatments as compared to "cellular therapy". The control "empty" vector, without antisense anti IGF-I cDNA, used to prepare "vaccines" in animal models previously described, has never shown influence for immune anti-tumor response [3] [43]. 


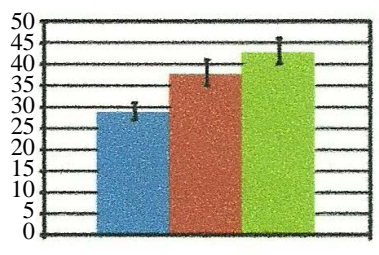

$\mathrm{CD}^{+}$

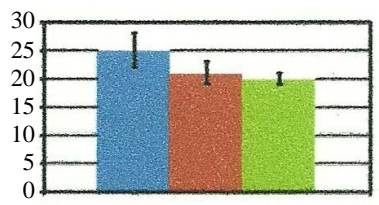

$\mathrm{CD}^{+} 11 \mathrm{~b}$

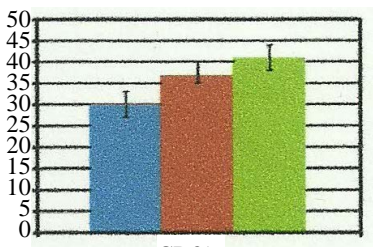

$\mathrm{CD}^{+}$

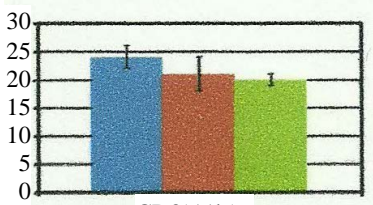

$\mathrm{CD}^{+} 11 \mathrm{~b}^{+}$

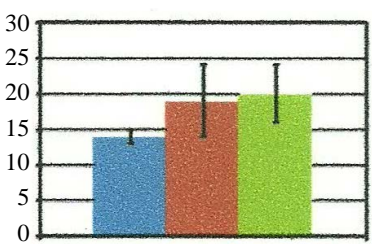

$\mathrm{CD}^{+} 28^{+}$

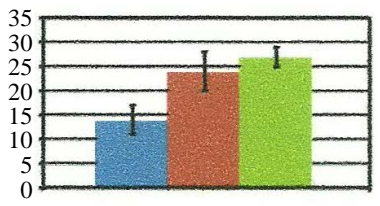

$\mathrm{CD}^{+}{ }^{+} 11 \mathrm{~b}$

(a)

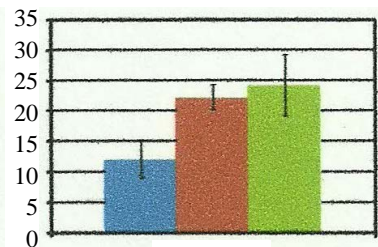

$\mathrm{CD}^{+}{ }^{+} 8^{+}$

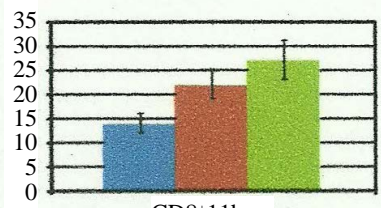

(c)

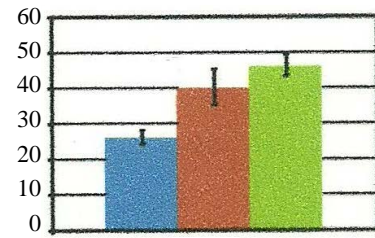

$\mathrm{CD}^{+}$

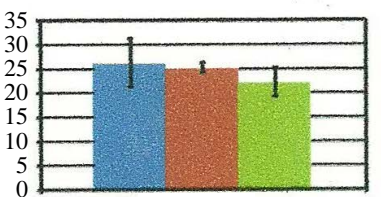

$\mathrm{CD}^{+} 11 \mathrm{~b}$

(b)

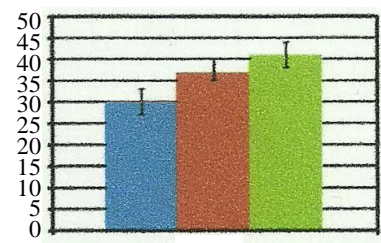

$\mathrm{CD}^{+}$

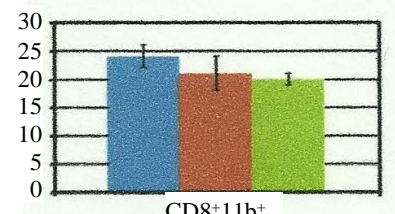

$\mathrm{CD}^{+} 11 \mathrm{~b}^{+}$

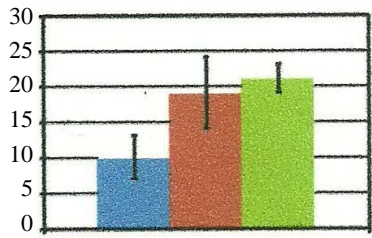

$\mathrm{CD}^{+} 28^{+}$

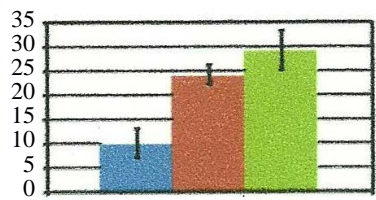

$\mathrm{CD}^{+} 11 \mathrm{~b}$

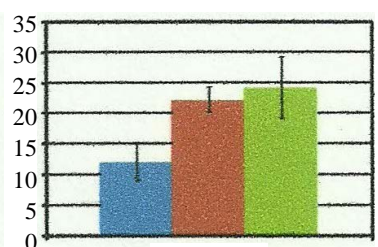

$\mathrm{CD}^{+} 28^{+}$

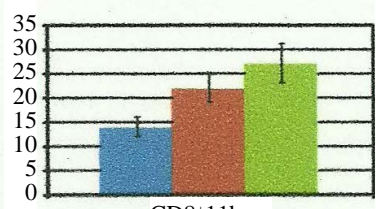

$\mathrm{CD}^{+} 11 \mathrm{~b}^{-}$

(d)

Figure 6. Flow cytometric peripheral blood lymphocyte CD marker patterns following cellular gene therapy in human cancers. Examples of cancers of three tissue derivatives are shown as follows: neuroectodermal-glioblastoma multiforme (a); entodermal-colon adenocarcinoma (b); mesodermal-ovarian carcinoma (c) and prostate adenocarcinoma (d). CD molecules were labelled in peripheral blood lymphocytes (PBL) obtained from pre-vaccinated and "vaccinated" cancer patients. Each of the first column corresponds to data obtained before vaccinations; each second and third column corresponds to data obtained after one and two successive cellular vaccinations (IGF-I antisense/triple helix cells). Two cases of each of the designated cancers were examined (bar graphs represent the median value of the two cases). Data are expressed as percent of positive cells when compared to the isotype control. Difference in percentage of $\mathrm{CD}^{+} \mathrm{CD} 11 \mathrm{~b}^{-}$and $\mathrm{CD}^{+} \mathrm{CD} 28^{+}$subpopulations before and after vaccination was strongly significant with a range of $\mathrm{p}$ from 0.001 to 0.02 according to the Student's $t$ test, and weakly significant concerning the decreasing $\mathrm{CD}^{+} \mathrm{CD} 11 \mathrm{~b}^{+}$subpopulation from the relevant patients. The $\mathrm{p}$ value for $\mathrm{CD}^{+}, \mathrm{CD}^{+} 28^{+}$and $\mathrm{CD}^{+} 11 \mathrm{~b}^{-}$(below 0.01 ) are illustrated in the bar graph for statistical significance.

The clinical results obtained in the University Hospital of Bromberg were as follows: two glioblastoma patients included in the group of "cellular therapy" have survived 19 and 24 months, respectively (beginning from day 0 - diagnosis of malignant glioma, followed by surgery, radiotherapy and antisense/triple helix cell injections). Two glioblastoma patients included in the group of "membrane therapy" have survived 9.5 and 10 months respectively-starting from surgery followed by radiotherapy and injection of cell membranes. The results observed in the group of glioblastoma patients treated with "membrane therapy", were not so different from those obtained in the third group treated by classical therapy; in the last group median survival was as 10 and 11 months. For this reason, admitting that the group of glioblastoma patients treated with antisense/triple helix cell injection has given the significant results, all other cancer patients (age 20 - 65 years: two cases of liver, colon, ovary, uterus and prostate cancer diseases) were treated, after surgery and radiotherapy with this type of "cellular therapy". Moreover the period of 19 months, was chosen as the end of clinical observations in all treated cancer patients. At 19 months, all these cancer patients were alive and the treatments were well tolerated (we do not include the details of clinical observations concerning different types of treated cancers, because it is not the subject of this work). The only secondary observed effect including glioblastoma patients, was that of increased temperature up to $38^{\circ} \mathrm{C}-39^{\circ} \mathrm{C}$ persisting during two-three days after every of cell vaccination. 
As to the patients treated in University Hospitals of Cleveland using antisense IGF-I "cellular therapy" (two cell injections), two of the treated patients forming a group of maximum median OS have both survived 19 months. Other group of three patients, have not responded so positively to the therapy, showing the median survival compared with that of "membrane" therapy. The therapy done in the USA has shown that the number of cell vaccinations (between one and four) was not related to the median OS. Concerning serial MRI/CT performed in USA patients: 1 - 2 month intervals before vaccine showed continuous growth of the intra cerebral tumor. MRI one month post vaccination showed first evidence of an unequivocal decrease in size of tumors viewed by radiology in University Hospitals of Cleveland. Moreover, all patients treated in the USA had advanced disease with cerebral edema at the time of first treatment with vaccine, and also were receiving treatment with high dose of decadron or related steroids to reduce the effect of CNS edema. This of course has caused further jeopardy to the immune system, and can explain the relatively negative results in three last treated cases.

To summarize the obtained results, the following schema of immuno-gene therapy mechanism was proposed (Figure 7).

\section{Ethical Consideration}

Human experiments were conducted in accordance with the Declaration of Helsinki (1964). The experiment was conducted with the understanding and the consent of the human subject. The responsible Ethical Committees have approved the experiments.

Injection of cell “vaccines”

Transfected glioma cells \& Transfected apoptotic glioma cells

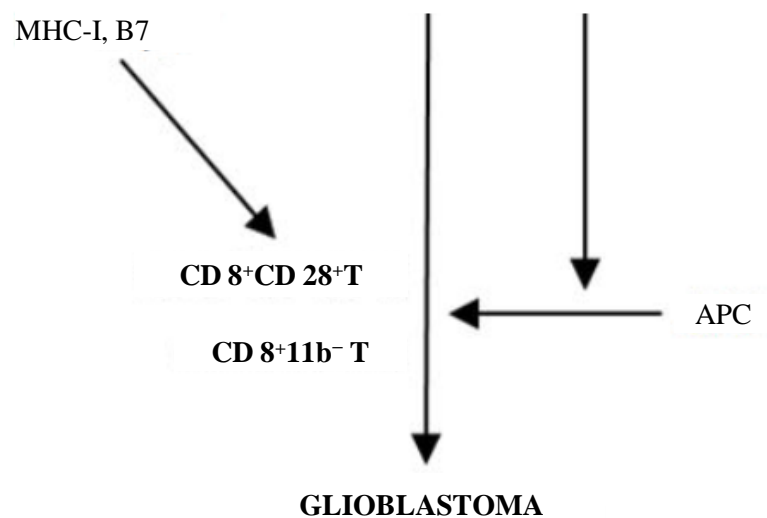

Figure 7. Mechanism of anti-gene anti IGF-I (antisense/triple helix) therapy of malignant tumours. The case of glioblastoma therapy; hypothetically, the same mechanism should exist in the treatment of other tumours expressing IGF-I. Tumour cells are transfected in vitro with a vector encoding IGF-I cDNA in antisense orientation (Figure 1), or with a vector inducing a formation of triple helix IGF-I structure. The transfected tumor glial cells, in absence of IGF-I, become immunogenic-expressing MHC-I and B7 molecules, and apoptotic as follows. The expression of MHC-I is due to the presence of TAP1; the expression of $\mathrm{B} 7$ is related directly with signal transduction pathway: TK/IRS/PI3K/PKC; the phenomenon of apoptosis is also related with signal transduction pathway: TK/ IRS/PI3K/AKT/Bcl2 [7] [10] [18] [47]-[51]. After in vivo injection, together with the antigen presenting cells, APC, they activate the T CD8 (CD8CD28) lymphocytes inducing immune anti tumor response against the malignant glioma (expressing MHC-I) [7] [19] [52] [53]. In conclusion, the mechanism of antisense therapy is a combination of an augmentation of the immune anti-tumour response and of an inhibition of signal transduction pathway that is involved in the transformed phenotype of the tumour. 
The approval for the gene therapy clinical trial (based on NIH clinical protocol $n^{\circ} 1602$, Bethesda, Maryland, 24/11/1993), containing scientific basis of methodology, cell therapy product standardization of preparation, detailed clinical protocol including inclusion criteria and exclusion criteria (i.e. HIV and EBV active infection) and the letter of agreement, was administrated by the Bioethical Commissions of the L. Rydygier Medical University, Bromberg (Bydgoszcz), Jagiellonian University, Cracow, Poland ( $n^{\circ} \mathrm{KB} / 176 / 2001,28 / 06 / 2002$, and $n^{\circ}$ KBET/ 184/L/2000, 21/09/2000), La Sabana University, Chia, Colombia, no P 004-10, 15/12/2010, Cartagena University Hospital of the Caribbean (preclinical study), Colombia, no 3-19/10/2011, and registered by international Wiley Gene Therapy Clinical Trial database, Stockholm, n 635 and 636 (J Gene Med, updated 2002). The protocol was verified by Ministry of Health, AFSSAPS Committee, Paris, France, 03/06/2005, and by NATO Science program 2003-2007 ( ${ }^{\circ}$ LST 980517).

\section{Discussion}

The immunogene and immune therapies may represent a novel approach for cancer therapy [54]. The glioblastoma, as well as other malignant tumors, were recently successfully treated by antisense therapy targeting TGF beta, using either antisense anti TGF beta expressing vector [55] or particularly applying the oligodeoxynucleotides [56] [57]. Using phosphorothioate TFG beta2 antisense oligonucleotides (AP-12009), an international phase II/III study was initiated in patients with TGF beta-overexpressing tumors such as high-grade gliomas, and by 2005-2006 the trial was ongoing in over 140 patients with anaplastic astrocytoma (AA) or glioblastoma; the treatment was very well tolerated. In 2007, overall survival was 24 months, and in the control group, survival was 20 months [56] [58] [59]. Results from the clinical trials concerning other tumors over expressing TGF beta were also recently published (pancreatic carcinoma, metastatic melanoma or advanced colorectal carcinoma); the treatment was well tolerated in all types of tumor diseases [56]. Other antisense approaches of malignant tumor treatment have been developed recently, since 2001, especially those of antisense anti IGF-I-Receptor [11]. AS IGF-I-R strategy of treatment of glioblastoma [Andrews et al., 2001] was not continued. It seems that this therapy could be more efficient if the cell "vaccines" were prepared after cloning of IGF-I-R antisense cells for MHC-I expression. In anti-gene anti IGF-I approach, we have applied both antisense and triple helix technologies, permitting to stop simultaneously the expression of IGF-I on translation and transcription levels [7]. Moreover, in vivo AS IGF-I approach was also developed [60]; 45 patients with PHC were co-transfected in vivo with antisense IGF-I expression vector and sense B7.1 expression vector. At two years following treatment of PHC stage II, there was marked reduction in tumor recurrence-from $62 \%$ to $20 \%$. Using described here IGF-I antisense/triple helix strategy, all treated patients have well tolerated the three injections of transfected cancer cells. The PBL cells have shown an increase in $\mathrm{CD} 8^{+} \mathrm{CD} 28^{+}$molecules with a characteristic switching from $\mathrm{CD}^{+} 11 \mathrm{~b}^{+}$to $\mathrm{CD}^{+} 11 \mathrm{~b}^{-}$phenotype, observed after two cell vaccinations, reflecting the enhanced activation of cytotoxic T-cells in blood. These results concerning the switching $\mathrm{CD}^{+} 11 \mathrm{~b}^{+}$to $\mathrm{CD}^{+} 11 \mathrm{~b}^{-}$in different treated tumors have confirmed previously obtained data in glioblastoma and hepatoma treatment using antisense anti IGF-I approach [40] [43]. The work in progress has also shown in different treated tumors described here, an increased percentage of T CD25 (interleukin-2 receptor), in the context of CD4, which has confirmed the results obtained in glioblastoma treatment. The only secondary observed effect was increased temperature, $38^{\circ} \mathrm{C}-39^{\circ} \mathrm{C}$, confirming the immune response induced by antisense/triple helix "vaccines". Regarding injection of cell membranes, the switching mentioned earlier was not significant. The challenge of injection of membranes, isolated from IGF-I antisense/triple helix transfected cells expressing MHC-I, has proved that the whole transfected cell population is necessary to produce an in vivo anti-tumor effect. At first, the cytoplasm of the transfected cells contains the IGF-I antisense RNA and IGF-I triple helix RNA-DNA structures constituting the principle of anti-gene cellular therapy [37]. Next, the cellular therapy described here has shown that both cell populations, as well MHC-I and B7 expressing transfected cells as apoptotic cells, are necessary to induce in vivo an immune anti-tumor response involving APC activating CD8 ${ }^{+} \mathrm{T}$ cells [23] [61]; it was previously demonstrated that doubly transfected cells, using antisense anti MHC-I and anti B7 vectors, lose their apoptotic and immune anti-tumor characters [20] [24]. This way, it was shown that both processes-immunogenicity (MHC-I and B7 expression) and apoptosis, "work" together. On the other side we have previously compared the efficiency of gene therapy - using the injection of IGF-I AS nucleotides and that of described here "cellular therapy" much more promising. In gene therapy approach, after the injection of IGF-I AS nucleotides directly to the tumor, the cancer cells internalizing AS nucleotides could not become immediately immunogenic to induce the 
rapid immune response, and for the same reason to develop the efficient apoptosis. Moreover, in the gene therapy, the co-transfection with B7 expression vector was necessary to reinforce the immune response [43] [60].

The immune criteria of used vaccines were strongly related to the preparation of cancer cells to be used as vaccine. Cancer cells cultivated under stem cell-permissive conditions more closely reflect the tumor of origin, including the genetic profile, than the parental tumor adherently growing cells under conventional cultivation conditions [62] [63]. In our experimental clinical trial, to avoid this effect of "contamination" increased by numerous passages, the primary cancers cells and transfected cancer cells "vaccines" were systematically cloned after every passage to obtain in vitro, in the first case 100\% IGF-I (+), MHC-I (-), and in the second case $100 \%$ IGF-I (-), MHC-I (+) expression. Moreover, in parallel to these criteria, another criteria was obligatory to produce the immune anti-tumor effect of "vaccines": the cell vaccines were composed of higher characterized cancer transfected cells and of apoptotic derived cancer transfected cells (mixture 50:50).

The mechanism of antisense therapy targeting growth factors and their receptors is a combination of an augmentation of the immune anti-tumor response and of an inhibition of the signal transduction pathway-PI3K/ AKT/GWK3/GS - that is involved in the transformed phenotype of the tumor [7] [49]. Activation of the PI3K/ AKT/GWK3/GS pathway is mediated by some tyrosine kinase receptors, under the control of several growth factors and cytokines as EGF, PDGF, VEGF, TGFbeta, CSF and especially IGF-I, whose receptor, IGF-I-R, plays a principal role in the tumor growth process [7] [13] [14]. As far as PI3K/AKT/GWK3/GS pathway (in relation with glioma) is considered, it was recently demonstrated that in experimental antisense anti-glycogene synthetase, GS, tumor therapy, the transfeted AS GS cells were also immunogenic (MHC-I expression) [49] [50]. Anyway in AS GS strategy an immune anti-tumor response was not as striking as when using AS IGF-I approach. This shows that AS IGF-I appears as a dominant tool for the arrest of tumor progression. Moreover, targeting IGF-I instead of IGF-I receptor seems more efficient: because of downstream elements involved in the IGF-I-R transduction pathway, signals from IGF-I-R can be inappropriate or exaggerated [13]. Nevertheless, if crosstalk of IGF-I's related different pathways is considered, IGF-I, through its binding to IGF-I-R, which activates PI3K/AKT transduction cascade, has been reported to block the apoptosis pathway (IRS/PI3K/AKT/Bcl or AKT/GSK3 or $\mathrm{Ca}^{2+}$ or caspases). As to PI3K/AKT/GWK3/GS pathways of IGF-I AS or TGFbeta AS therapies, we cannot avoid the relation with PI3K/PKC/RAF/MAPK chain, and we cannot exclude that the inhibition of TK/PI3K/AKT pathway using AS IGF-I approach, can be reinforced by "side" effect of MAPK inhibition. The inhibitors of RAF targeting the ATP binding site, as well as the inhibitors of MAPK at a non-ATP site, were also introduced in cancer clinical trials [64] [65]. For most of the pathways that have been disclosed it has been a problem to develop selective molecules having a relevant clinical impact in malignant diseases, including uncured glioblastoma [66]. To target specific genetic defects, the antisense oligonucleotides have become one of the important anti-cancer approaches used in clinical trials [28].

The immune anti-tumor response was signalled as a principal mechanism of antisense technology, as well using anti TGF beta technique as anti IGF-I and IGF-I-R inhibiting growth factors and their signalling pathway [24] [55]. The final result of AS IGF-I approach including the TK/PI3K/AKT pathway elements inhibition is an immune response mediated in vivo by lymphocytes T CD8 and APC cells [7] [14]. As far as the relationship between anti-gene anti IGF-I technology and immunogenicity is considered, the absence of IGF-I synthesis in "antisense" and "triple-helix" transfected cells, could lead to a compensative increase in IGF-I receptor (tyrosine kinase); IGF-I and IGF-II present in foetal calf serum of culture medium, as well as intracellular IGF-II can interact with the type I receptor [22]. Indeed, the increase of IGF-I receptor level could explain the expression of B7. There is a known relation between the signal transduction pathway of tyrosine kinase and the induction of B7 molecules: enhancement in B-7 co-stimulation through a cAMP mechanism linked to tyrosine kinase of the CD 28 receptor has been previously reported [18]. The co-stimulatory B7 molecule in antigen presenting cells (APCs) is bound to the counter-receptor CD28 and/or CTLA4 expressed on the T-cells [52] [67]. B7 was present in different antisense and triple helix anti IGF-I transfected cancer cells but absent in transfected human hepatoma and in previously described murine hepatomas.

As to the MHC-I (HLA) expression in AS and TH cells, this molecule is strictly related to TAP-1 presence; TAP-1, TAP-2 tightly linked to LMP-2 and LMP-7 [17] [68]-[71] are multiple components of the endogenous, antigen presentation pathway machinery. Deficiencies in expression of TAP-1, TAP-2 and LMP-7 were observed human glioma cell lines. Following down-regulation of IGF-1 by transfection with AS IGF-I vector, the deficiencies in components of the MHC-1 antigen presentation pathway were up-regulated (with restoration of 
TAP and LMP) [10]. Our previous results have also demonstrated that the expression of MHC-I in human transfected hepatoma cells was much higher than that in transfected human glioma cells [23]. This strong expression of MHC-I in human transfectedhepatoma lines (5 times, compared to human transfected glioma lines) could explain that the presence ofMHC-I was sufficient to induce T CD8 lymphocytes response in the absence of B7 antigen. To summarize the immune anti-tumor mechanism of anti-gene anti IGF-I strategy, this aspect was published previously [22] [43]. As far as largely studied glioma treatment is considered, and similarly other concerned tumors, the mechanism concerns the reaction between activated lymphocytes expressing CD8CD28, and immune molecules MHC-I and B7. The following chain reaction could occur: cultured cloned glioma cells [IGF-I (+), MHC-I (-), B7 (-)] => cultured transfected anti-gene IGF-I cells [IGF-I (-), MHC-I $(+)$, B7 (+)] => injection (glioblastoma patients) $=>$ induction of CTL CD8 $(+)$ CD28 $(+)=>$ destruction of injected transfected anti-gene IGF-I cells [IGF-I (-), MHC-I (+), B7 (+)] and arrest of a solid glioma tumor [IGF-I (+/-), MHC-I $(+)$, B7 (+)] (see also legend of Figure 7).

\section{Conclusions}

The treatment options for patients with advanced malignant tumors, including brain tumor glioblastoma (current mortality $100 \%$ ), such as surgery, radiation or hormone therapy are limited in efficacy, therefore the search for new strategies like chemotherapy [72], use of inhibitors, including antibodies, antisense oligonucleotides, short peptides and other small molecules [1] [2] [7] [73]-[75], or cellular immune therapy [19] [76] represents a permanent challenge. The current clinical strategies for the treatment of gliomas are usually a combination of chemotherapy and use of different types of inhibitors (imatinib, gefitinib) including antibodies (i.e. avastin), targeting growth factors and their receptors [72] [73] [77] [78]. A pharmacological strategy—the use of temozolomide introduced by R. Stupp, has offered a new hope for treatment of glioblastoma. However, although median survival has reached almost a year and a half, we are still far from victory [7] [72] [73] [79] [80].

Our presented work focuses on the criteria established for methodology of anti IGF-I gene therapy analyzing our different previous basic and clinical results obtained in Europe, USA and Asia, following our previous NATO science program (see Acknowledgement), and published recently [43] [51], permitting to start Phase I and II in South America (Colombia). This way we have established the common criteria for selection of vaccines (expression of IGF-I, MHC-I, B7) and of PBL cells markers (CD8 ${ }^{+}$related molecules) in patients presenting the arrest of growing tumors.

The various therapies in the treatment of cancer are still experimental [81]. A number of strategies for inhibiting gene expression have been developed including the triple helix approach, antisense cDNA and oligodeoxynucleotides. Among the new strategies in the efforts of treating malignant tumors expressing different growth factors, and more specifically IGF-I, TGF beta, VEGF or EGF [14] [65] [74] [82], the anti-gene therapy approach, either antisense or triple helix, appears as a promising solution [57] (Table 1). Although in the presented work only limited numbers of glioblastoma patients were treated, the clinical results obtained are positive (minimum survival has reached 19 months). The anti-gene anti IGF-I therapy, giving a strong immune antitumor response in different comparatively studied tumor diseases presents all characteristics of cell immunotherapy $\left(\mathrm{CD}^{+}\right.$and $\mathrm{CD}^{+} 8^{+}$expression in T lymphocytes, and MHC-I in relation with TAP-1 and -2 molecules in "vaccine" cells) [10] [83] including apoptotic phenomenon [7] [18] [44] [84]. We suggest that anti-gene cell therapy, giving comparable results to those of currently applied chemotherapy, inhibitors or antibodies [72] [73] [85], could be used either alone [57] [86] or as combined therapies i.e. antisense targeting simultaneously different elements of growth factors signalling pathway [49] [50] [63] [64], or as antisense/chemotherapy. The combined anti-cancer strategies considering the role of immune anti-tumor response [65] [77] [78] [87]-[91], including study of control CD8 (+) T-cell effect or functions [92], new tools of cell transfection [93] and especially the search for new onco-proteins [94] and growth factor targets [14] [50] [65] [95] [96] appear as the near future challenge. Among growth factors, targeting IGF-I system in relation with cancer therapy constitutes ongoing basic and clinical research [97]-[99]; the IGF-I being considered as one of the principal precancerous markers [3] [100] [101], has conducted to experiments on suppression of IGF-I expression in tumors, following directly by immuno-gene therapy of malignant tumors. Gene therapy, particularly cellular imunogene therapy, and cellular immunotherapy are currently among the most promising approaches for treatment of cancer diseases [78] [91] [102] [103]. As far as gene therapy is concerned, the technologies permitting higher transgene expression using either viral vectors or synthetic vectors, are in permanent study [39] [104]. 


\section{Acknowledgements}

We would like to thank Drs. Y. X. Pan (CWRU, Cleveland), H. T. Duc, A. Ly (INSERM, University of Paris XI), M. Bierwagen (University of Bromberg, Poland), M.-Y. Ardourel (University of Orleans), J. C. Dib, A. J. Bermudez (INS, Colombia) for helpful discussion of results and for suggestions concerning clinical trial phase II. We thank Dr. C. Crane for preparation of the tissue culture photos (INS, Bogota). This work was supported by the subventions of NATO Science program (CLG LST 980517), ICGT SA Society and INS-National Institute of Health, Bogota.

\section{References}

[1] Catuogno, S., Esposito, C.L., Quintavalle, C., Condorelli, G., de Franciscis, V. and Cerchia, L. (2012) Nucleic Acids in Human Glioma Treatment: Innovative Approaches and Recent Results. Journal of Signal Transduction, 2012, Article ID: 735135. http://www.hindawi.com/journals/jst/ http://dx.doi.org/10.1155/2012/735135

[2] Caruso, G. and Caffo, M. (2014) Antisense Oligonucleotides in the Treatment of Cerebral Gliomas Review of Concerning Patents. Recent Patents on CNS Drug Discovery. http://benthamscience.com/journal/index.php?journalID=rpcn: 2212-3954

[3] Trojan, J., Johnson, T.R., Rudin, S.D., Ilan, J., Tykocinski, M.L. and Ilan, J. (1993) Treatment and Prevention of Rat Glioblastoma by Immunogenic C6 Cells Expressing Antisense Insulin-Like Growth Factor I RNA. Science, 259, 94-99. http://www.sciencedirect.com/

[4] Rubenstein, J.L., Nicolas, J.F. and Jacob, F. (1984) L’ARN non sens (nsARN): Un outil pour inactiver spécifique mentl'expression d'un gène donné in Vivo [Nonsense RNA: A Tool for Specifically Inhibiting the Expression of a Gene in Vivo]. Comptes Rendus Academie des Sciences Paris, 299, 271-274.

[5] Derwan, P. (1992) Reagents for the Site-Specific Cleavage of Megabase DNA. Nature, 359, 87-88. http://www.nature.com/ http://dx.doi.org/10.1038/359087a0

[6] Helene, C. (1994) Control of Oncogene Expression by Antisense Nucleic Acids. European Journal of Cancer, 30, 1721-1726. http://www.sciencedirect.com/science/journal/09598049

[7] Trojan, J., Cloix, J.F., Ardourel, M.Y., Chatel, M. and Anthony, D. (2007) Insulin-Like Growth Factor Type I Biology and Targeting in Malignant Gliomas. Neuroscience, 145, 795-812.

http://dx.doi.org/10.1016/j.neuroscience.2007.01.021

[8] Ellouk-Achard, S., Djenabi, S., De Oliveira, G.A., Dessay, G., Duc, H.T., Zoar, M., Trojan, J., Claude, J.R., Sarasin, A. and Lafarge-Frayssinet, C. (1998) Induction of Apoptosis in Rat Hepatocarcinoma Cells by Expression of IGF-I Antisense c-DNA. Journal of Hepatology, 29, 807-818. http://www.journal-of-hepatology.eu/ http://dx.doi.org/10.1016/S0168-8278(98)80263-8

[9] Trabado, S., Van Binh, P.N., Martin, C., Lafarge-Frayssinet, C., Lone, Y.C., Trojan, J., Warnet, J.M. and Duc, H.T. (2007) Stimulation of Anti-Melanoma Immune Effectors via Modified Tumour Cells Exhibiting Inhibited IGF-I and Low CD9. Biomedicine \& Pharmacotherapy, 61, 494-498.

http://www.us.elsevierhealth.com/oncology/biomedicine-amp-pharmacotherapy-journal/07533322/ http://dx.doi.org/10.1016/j.biopha.2007.07.004

[10] Pan, Y., Trojan, J., Guo, Y. and Anthony, D.D. (2013) Rescue of MHC-1 Antigen Processing Machinery by DownRegulation in Expression of IGF-I in Human Glioblastoma Cells. PLoS ONE, 8, Article ID: e58428. http://www.plos.org/

[11] Andrews, D.W., Resnicoff, M., Flanders, A.E., Kenyon, L., Curtis, M., Merli, G., Baserga, R., Iliakis, G. and Aiken, R.D. (2001) Results of a Pilot Study Involving the Use of an Antisense Oligodeoxynucleotide Directed against the Insulin-Like Growth Factor Type I Receptor in Malignant Astrocytomas. Journal of Clinical Oncology, 19, 2189-2200. http://www.asco.org/press-center/journal-clinical-oncology

[12] Djavan, W., Aldert, M., Seitz, C. and Marberger, M. (2001) Insulin-Like Growth Factors and Prostate Cancer. World Journal of Urology, 19, 225-233. http://www.springer.com/medicine/urology/journal/345 http://dx.doi.org/10.1007/s003450100220

[13] Pollak, M.N., Schernhammer, E.S. and Hankinson, S.E. (2004) Insulin-Like Growth Factors and Neoplasia. Nature Review Cancer, 4, 505-518. http://www.nature.com/nrc/index.html http://dx.doi.org/10.1038/nrc1387

[14] Baserga, R. (2005) The Insulin-Like Growth Factor-I Receptor as a Target for Cancer Therapy. Expert Opinion on Therapeutic Targets, 9, 753-768. http://dx.doi.org/10.1517/14728222.9.4.753 
[15] Brooks, W.H., Latta, R.B., Mahaley, M.S., Roszman, T.L., Dudka, L. and Skaggs, C. (1981) Immunobiology of Primary Intracranial Tumors. Part 5: Correlation of a Lymphocyte Index and Clinical Status. Journal of Neurosurgery, 54, 331-337. http://thejns.org/toc/jns/current http://dx.doi.org/10.3171/jns.1981.54.3.0331

[16] Blanchet, O., Bourge, J.F., Zinszner, H., Israel, A., Kourilsky, P., Dausset, J., Degos, L. and Paul, P. (1992) Altered Binding of Regulatory Factors to HLA Class I Enhancer Sequence in Human Tumor Cell Lines Lacking Class I Antigen Expression. Proceedings of the National Academy of Science of the United States of America, 89, 3488-3492. http://www.pnas.org/content/ http://dx.doi.org/10.1073/pnas.89.8.3488

[17] Saji, M., Moriarty, J., Ban, T., Singer, D. and Kohn, L. (1992) Major Histocompatibility Complex Class I Gene Expression in Rat Thyroid Cells Is Regulated by Hormones, Methimazole and Iodide as Well as Interferon. Journal of Clinical Endocrinology and Metabolism, 75, 871-878. http://press.endocrine.org/loi/jcem

[18] Schwartz, R.H. (1992) Costimulation of T Lymphocytes: The Role of CD28, CTLA-4 and B7/BBI in Interleukin-2 Production and Immunotherapy. Cell, 71, 1065-1068. http://dx.doi.org/10.1016/S0092-8674(05)80055-8

[19] Wu, A., Wiesner, S., Xiao, J., Ericson, K., Chen, W., Hall, W.A., Low, W.C. and Ohlfest, J.R. (2007) Expression of MHC-I and NK Ligands on Human CD133 ${ }^{+}$Gliomacells: Possible Targets of Immunotherapy. Journal of Neuro-Oncology, 83, 121-131. http://www.bioxbio.com/if/html/J-NEURO-ONCOL.html

[20] Trojan, J., Duc, H.T., Upegui-Gonzalez, L., Hor, F., Guo, Y., Anthony, D.D. and Ilan, J. (1996) Presence of MHCI and B-7 Molecules in Rat and Human Glioma Cells Expressing Antisense IGF-I mRNA. Neuroscience Letters, 212, 9-12. http://www.sciencedirect.com/science/journal/03043940 http://dx.doi.org/10.1016/0304-3940(96)12770-1

[21] Trojan, J., Johnson, T., Rudin, S., Blossey, B., Kelley, K., Shevelev, A., Abdul-Karim, F., Anthony, D., Tykocinski, M., Ilan, J. and Ilan, J. (1994) Gene Therapy of Murine Teratocarcinoma: Separate Functions for Insulin-Like Growth Factors I and II in Immunogenicity and Differentiation. Proceedings of the National Academy of Science of the United States of America, 91, 6088-6092. http://www.pnas.org/content/

[22] Lasfarge-Frayssinet, C., Duc, H.T., Frayssinet, C., Sarasin, A., Anthony, D.D., Guo, Y. and Trojan, J. (1997) Antisense Insulin-Like Growth Factor I Transferred into a Rat Hepatoma Cell Line Inhibits Tumorigenesis by Modulating Major Histocompatibility Complex I Cell Surface Expression. Cancer Gene Therapy, 4, 276-285. http://www.researchgate.net/journal/1476-5500_Cancer_gene_therapy

[23] Upegui-Gonzalez, L.C., Ly, A., Sierzega, M., Jarocki, P., Trojan, L.A., Duc, H.T., Pan, Y., Shevelev, A., Henin, D., Anthony, D.D., Nowak, W., Popiela, T. and Trojan, J. (2001) IGF-I Triple Helix Strategy in Hepatoma Treatement. Hepato-Gastroenterology, 48, 656-662. http://www.hepatogastroenterology.org/

[24] Ly, A., Duc, H.T., Kalamarides, M., Trojan, L.A., Pan, Y., Shevelev, A., François, J.-C., Noël, T., Kane, A., Henin, D., Anthony, D.D. and Trojan, J. (2001) Human Glioma Cells Transformed by IGF-I Triple-Helix Technology Show Immune and Apoptotic Characteristics Determining Cell Selection for Gene Therapy of Glioblastoma. Molecular Pathology, 54, 230-239. http://jcp.bmj.com/ http://dx.doi.org/10.1136/mp.54.4.230

[25] Weintraub, H., Izant, J.G. and Harland, R.M. (1985) Antisense RNA as a Molecular Tool for Genetic Analysis. Trends in Genetics, 1, 23-25. http://www.journals.elsevier.com/trends-in-genetics/

[26] Green, P.J., Pines, O. and Inouye, M. (1986) The Role of Antisense RNA in Gene Regulation. Annual Review of Biochemistry, 55, 569-597. http://www.annualreviews.org/journal/biochem http://dx.doi.org/10.1146/annurev.bi.55.070186.003033

[27] Merino, E., Balbas, P., Puente, J.L. and Bolivar F. (1994) Antisense Overlapping Open Reading Frames in Genes from Bacteria to Humans. Nucleic Acids Research, 22, 1903-1908. http://www.oxfordjournals.org/our_journals/nar/about.html http://dx.doi.org/10.1093/nar/22.10.1903

[28] Dias, N. and Stein, C.A. (2002) Antisense Oligonucleotides: Basic Concepts and Mechanisms. Molecular Cancer Therapeutics, 1, 347-355. http://mct.aacrjournals.org/site/misc/journal ifora.xhtml

[29] Galderisi, U., Cascino, A. and Giordano, A. (1999) Antisense Oligonucleotides as Therapeutic Agents. Journal of Cellular Physiology, 181, 251-257. http://www.bioxbio.com/if/html/J-CELL-PHYSIOL.html http://dx.doi.org/10.1002/(SICI)1097-4652(199911)181:2<251::AID-JCP7>3.0.CO;2-D

[30] Bennett, C.F., Butler, M., Cook, P.D., Geary, R.S., Levin, A.A., Mehta, R., Teng, C.L., Desmukh, H., Tillman, L. and Hardee, G. (2000) Antisense Oligonucleotides-Based Therapeutics. In: Templeton, N.S. and Lasic D.D., Eds., Gene Therapy, Marcel Dekker, New York, 305-332.

[31] Tsai, Y.J., Hu, C.C., Chu, C.C. and Imae, T. (2011) Intrinsically Fluorescent PAMAM Dendrimer as Gene Carrier and Nanoprobe for Nucleic Acids Delivery: Bioimaging and Transfection Study. Biomacromolecules, 12, 4283-4290. 
http://pubs.acs.org/toc/bomaf6/current

[32] Scaggiante, B., Morassutti, C., Tolazzi, G., Michelutti, A., Baccarani, M. and Quadrifoglio, E. (1994) Effect of Unmodified Triple Helix-Forming Oligodeoxyribonucleotide Targeted to Human Multidrug-Resistance Gene mdr1 in MDR Cancer Cells. FEBS Letters, 352, 380-384. http://www.journals.elsevier.com/febs-letters/ http://dx.doi.org/10.1016/0014-5793(94)00995-3

[33] Thomas, T., Faaland, C., Gallo, M. and Thomas, I. (1995) Suppression of c-myc Oncogene Expression by a PolyamineComplexed Triplex Forming Oligonucleotide in MCF-7 Breast Cancer Cells. Nucleic Acids Research, 23, 3594-3599. http://www.oxfordjournals.org/our_journals/nar/about.html http://dx.doi.org/10.1093/nar/23.17.3594

[34] Vasquez, K.M. and Wilson, I.H. (1998) Triplex-Directed Modification of Genes and Gene Activity. Trends in Biochemical Science, 23, 4-9. http://www.journals.elsevier.com/trends-in-biochemical-sciences/

[35] Mayfield, C., Ebbinghaus, S., Gee, I., Jones, D., Rodu, B., Squibb, M. and Miller, D. (1994) Triplex Formation by the Human Haras Promoter Inhibits Spl Binding and in Vitro Transcription. Journal of Biological Chemistry, 69, 1823218238. http://www.jbc.org/site/misc/about.xhtml

[36] Rininsland, F., Johnson, T.R., Chernicky, C.L., Schulze, E., Burfeind, P. and Ilan, J. (1997) Suppression of InsulinLike Growth Factor Type I Receptor by a Triple-Helix Strategy Inhibits IGF-I Transcription and Tumorigenic Potential of Rat C6 Glioblastoma Cells. Proceedings of the National Academy of Science of the United States of America, 94, 5854-5859. http://www.pnas.org/content/ http://dx.doi.org/10.1073/pnas.94.11.5854

[37] Shevelev, A., Burfeind, P., Schulze, E., Rininsland, F., Johnson, T., Trojan, J., Chernicky, C., Hélène, C., Ilan, J. and Ilan, J. (1997) Potential Triple Helix-Mediated Inhibition of IGF-I Gene Expression Significantly Reduces Tumorigenicity of Glioblastoma in an Animal Model. Cancer Gene Therapy, 4, 105-112. http://www.researchgate.net/journal/1476-5500 Cancer gene therapy

[38] Aggarwal, B., Schwarz, L., Hogan, M. and Rando, R. (1996) Triple Helix-Forming Oligodeoxyribonucleotides Targeted to the Human Tumor Necrosis Factor (TNF) Gene Inhibit TNF Production and Block the TNF Dependent Growth of Human Glioblastoma Tumor Cells. Cancer Research, 56, 5156-5164. http://cancerres.aacrjournals.org/

[39] Sia, K.C., Chong, W.K., Ho, I.A., Yulyana, Y., Endaya, B., Huynh, H. and Lam, P.Y. (2010) Hybrid Herpes Simplex Virus/Epstein-Barr Virus Amplicon Viral Vectors Confer Enhanced Transgene Expression in Primary Human Tumors and Human Bone-Marrow-Derived Mesenchymal Stem Cells. The Journal of Gene Medicine, 12, 848-858.

http://onlinelibrary.wiley.com/journal/10.1002/(ISSN)1521-2254 http://dx.doi.org/10.1002/jgm.1506

[40] Trojan, L.A., Kopinski, P., Mazurek, A., Chyczewski, L., Ly, A., Jarocki, P., Niklinski, J., Shevelev, A., Trzos, R., Pan, Y., Gitis, D.J., Bierwagen, M., Czapiewska, J.L., Wei, M.X., Michalkiewicz, J., Henin, D., Popiela, T., Evrard, F., Kasprzak, H., Anthony, D.D. and Trojan, J. (2003) IGF-I Triple Helix Gene Therapy of Rat and Human Gliomas. Annales Academiae Medicae Bialostocensis (Roc Akad Med Bial), 48, 18-27. http://www.advms.pl/

[41] Popiela, T., Sierzega, M., Gach, T., Jarocki, P. and Trojan, J. (2003) Phase I Trial of Colorectal Cancer Immune Therapy Using Autologous Cancer Cells Transfected with an IGF-I Antisense Plasmid [Abstract]. Acta Chirurgica Belgica, 5, 2-3. http://www.researchgate.net/journal/0001-5458 Acta chirurgica Belgica

[42] Trojan, L.A., Ly, A., Kopinski, P., Ardourel, M.Y., Dufour, T., Duc, H.T., Kasprzak, H., Cloix, J.F., Wei, M.X., Chyczewski, L., Pan, Y., Chatel, M., Anthony, D.D. and Trojan, J. (2006) Antisense and Triple Helix Anti IGF-I Tumours Vaccines-Gene Therapy of Gliomas. International Journal of Cancer Research and Prevention, 2, 227-243. https://www.novapublishers.com/catalog/product_info.php?products_id=1675

[43] Trojan, L.A., Ly, A., Upegui-Gonzalez, L., Jarocki, P., Shevelev, A., Sierzega, M., Wei, M.X., Lafarge-Frayssinet, C., Kopinski, P., Pan, Y.J., Kulig, J., Anthony, D., Popiela, T., Duc, H.T. and Trojan, J. (2009) Antisense Anti IGF-I Therapy of Primary Hepatic Cancer. African Journal of Cancer, 1, 21-30.

http://www.researchgate.net/journal/1965-0817_Journal_africain_du_cancer_African_Journal_of_Cancer http://dx.doi.org/10.1007/s12558-008-0005-9

[44] Matlib, M.A., Kihara, M., Farrell, C. and Dage, R.C. (1988) The $\mathrm{Na}^{+}-\mathrm{Ca}^{2+}$ Exchange System in Vascular Smooth Muscle Cell Membrane Vesicles Isolated from Cultured Cells and from Tissue Is Similar. Biochemical and Biophysical Acta (BBA), Biomembranes, 939, 173-177. http://www.journals.elsevier.com/bba-general-subjects/ http://dx.doi.org/10.1016/0005-2736(88)90060-0

[45] Frankenberger, B., Pohla, H., Noessner, E., Willimsky, G., Papier, B., Pezzutto, A., Kopp, J., Oberneder, R., Blank enstein, T. and Schendel, D.J. (2005) Influence of CD80, Interleukin-2, and Interleukin-7 Expression in Human Renal Cell Carcinoma on the Expansion, Function, and Survival of Tumor-Specific CTLs. Clinical Cancer Research, 11, 1733-1742. http://www.bioxbio.com/if/html/CLIN-CANCER-RES.html

[46] Naoyuki, T., Takayoshi, M. and Yoshikatsu, E. (2005) Human Monocyte-Derived Dendritic Cells Pulsed with Wild- 
Type p53 Protein Efficiently Induce CTLs against p53 Overexpressing Human Cancer Cells. Clinical Cancer Research, 11, 1312-1318. http://www.bioxbio.com/if/html/CLIN-CANCER-RES.html

[47] Patel, S., Doble, B. and Woodgett, J.R. (2004) Glycogen Synthase Kinase-3 in Insulin and Wnt Signalling: A DoubleEdged Sword? Biochemical Society Transactions, 32, 803-808. http://dx.doi.org/10.1042/BST0320803

[48] Beckner, M.E., Gobbel, G.T., Abounader, R., Burovic, F., Agostino, N.R., Laterra, J. and Pollack, I.F. (2005) Glycolytic Glioma Cells with Active Glycogen Synthase Are Sensitive to PTEN and Inhibitors of PI3K and Gluconeo Genesis. Laboratory Investigation, 85, 1457-1470. http://www.bioxbio.com/if/html/LAB-INVEST.html

[49] Premkumar, D.R., Arnold, B., Jane, E.P. and Pollack, I.F. (2006) Synergistic Interaction between 17-AAG and Phosphatidylinositol 3-Kinase Inhibition in Human Malignant Glioma Cells. Molecular Carcinogenesis, 45, 47-59.

http://onlinelibrary.wiley.com/journal/10.1002/(ISSN)1098-2744 http://dx.doi.org/10.1002/mc.20152

[50] Ardourel, M.Y., Blin, M., Moret, J.L., Dufour, T., Duc, H.T., Hevor, T., Trojan, J. and Cloix, J.F. (2007) A New Putative Target for Antisense Gene Therapy of Glioma: Glycogen Synthetase. Cancer Biology and Therapy, 6, 719-723. http://www.landesbioscience.com/journals/cbt/ http://dx.doi.org/10.4161/cbt.6.5.4232

[51] Trojan, J., Ly, A., Wei, M.X., Kopinski, P., Ardourel, M.Y., Pan, Y., Trojan, L.A., Dufour, D., Shevelev, A., Andres, C., Chatel, M., Kasprzak, H., Anthony, D.D. and Duc, H.T. (2010) Antisense Anti-IGF-I Cellular Therapy of Malignant Tumours: Immune Response in Cancer Patients. Biomedicine \& Pharmacotherapy, 64, 576-578. http://www.journals.elsevier.com/biomedicine-and-pharmacotherapy/

[52] Harding, F.A., McArthur, J.G., Gross, J.A., Raulet, D.H. and Allison, J.P. (1992) CD28-Mediated Signalling Co-Stimulates Murine T Cells and Prevents Induction of Anergy in T-Cell Clones. Nature, 356, 607-609.

http://www.nature.com http://dx.doi.org/10.1038/356607a0

[53] Di Tomaso, T., Mazzoleni, S., Wang, E., Sovena, G., Clavenna, D., Franzin, A., Mortini, P., Ferrone, S., Doglioni, C., Marincola, F.M., Galli, R., Parmiani, G. and Maccalli, C. (2010) Immunobiological Characterization of Cancer Stem Cells Isolated from Glioblastoma Patients. Clinical Cancer Research, 16, 800-813.

http://clincancerres.aacrjournals.org/ http://dx.doi.org/10.1158/1078-0432.CCR-09-2730

[54] Migliorini, D., Dietrich, P.Y. and Walker, P.R. (2013) Maximizing Output from Current Glioma Vaccine Trials to Construct Robust Next Generation Immunotherapies. Immunotherapy, 5, 1147-1150.

http://www.futuremedicine.com/loi/imt http://dx.doi.org/10.2217/imt.13.115

[55] Fakhrai, H., Dorigo, O., Shawler, D.L., Lin, H., Mercola, D., Black, K.L., Royston, Y. and Sobol, R.E. (1996) Eradication of Established Intracranial Rat Gliomas by Transforming Growth Factor Beta Antisense Gene Therapy. Proceedings of the National Academy of Science of the United States of America, 93, 2909-2914.

http://www.pnas.org/content/ http://dx.doi.org/10.1073/pnas.93.7.2909

[56] Schlingensiepen, K.H., Schlingensiepen, R., Steinbrecher, A., Hau, P., Bogdahn, U., Fischer-Blass, B. and Jachimczak, P. (2006) Targeted Tumor Therapy with the TGF-Beta2 Antisense Compound AP 12009. Cytokine Growth Factor Review, 17, 129-139. http://www.journals.elsevier.com/cytokine-and-growth-factor-reviews/ http://dx.doi.org/10.1016/j.cytogfr.2005.09.002

[57] Schlingensiepen, K.H., Fischer-Blass, B., Schmaus, S. and Ludwig, S. (2008) Antisense Therapeutics for Tumor Treatment: The TGF-Beta2 Inhibitor AP 12009 in Clinical Development against Malignant Tumors. Recent Results Cancer Research, 177, 137-150. http://www.springer.com/series/392 http://dx.doi.org/10.1007/978-3-540-71279-4_16

[58] Hau, P., Jachimczak, P. and Bogdahn, U. (2009) Treatment of Malignant Gliomas with TGF-Beta2 Antisense Oligonucleotides. Expert Review of Anticancer Therapy, 9, 1663-1674. http://informahealthcare.com/journal/ery http://dx.doi.org/10.1586/era.09.138

[59] Hau, P., Jachimczak, P., Schlaier, J. and Bogdahn, U. (2011) TGF- $\beta 2$ Signaling in High-Grade Gliomas. Current Pharmaceutical Biotechnology, 12, 2150-2157. http://www.speciation.net/Database/Journals/Current-Pharmaceutical-Biotecnology-;i3597

[60] Anthony, D.D. (1997) Ex Vivo and in Vivo IGF-1 Antisense RNA Strategies for Treatment of Cancers in Humans. Cancer Gene Therapy, 2, 322. http://www.nature.com/cgt/archive/index.html

[61] Matthew, L., Saiter, B. and Bhardwag, N. (1998) Dendritic Cells Acquire Antigen from Apoptotic Cells and Induce Class I-Restricted CTLs. Nature, 392, 86-89. http://www.nature.com/ http://dx.doi.org/10.1038/32183 
[62] Galli, R., Binda, E., Orfanelli, U., Cipelletti, B., Gritti, A., De Vitis, S., Fiocco, R., Foroni, C., Dimeco, F. and Vescovi, A. (2004) Isolation and Characterization of Tumorigenic, Stem-Like Neural Precursors from Human Glioblastoma. Cancer Research, 64, 7011-7021. http://cancerres.aacrjournals.org/

[63] Tunici, P., Bissola, E., Lualdi, E., Pollo, B., Cajola, L., Broggi, G., Sozzi, G. and Finocchiaro, G. (2004) Genetic Alterations and in Vivo Tumorigenicity of Neurospheres Derived from an Adult Glioblastoma. Molecular Cancer, 6, 3-25. http://www.molecular-cancer.com/

[64] Downward, J. (2003) Targeting RAS Signalling Pathways in Cancer Therapy. Nature Review Cancer, 3, 11-22. http://dx.doi.org/10.1038/nrc969

[65] Lo, H.W. (2010) Targeting Ras-RAF-ERK and Its Interactive Pathways as a Novel Therapy for Malignant Gliomas. Current Cancer Drug Targets, 10, 840-848. http://benthamscience.com/journal/index.php?journalID=ccdt http://dx.doi.org/10.2174/156800910793357970

[66] Goudar, R.K., Shi, Q., Hjelmeland, M.D., Keir, S.T., McLendon, R.E., Wikstrand, C.J., Reese, E.D., Conrad, C.A., Traxler, P., Lane, H.A., Reardon, D.A., Cavenee, W.K., Wan, X.F., Bigner, D.D., Friedman, H.S. and Rich, J.N. (2005) Combination Therapy of Inhibitors of Epidermal Growth Factor Receptor/Vascular Endothelial Growth Factor Receptor 2 (AEE788) and the Mammalian Target of Rapamycin (RAD001) Offers Improved Glioblastoma Tumor Growth Inhibition. Molecular Cancer Therapeutics, 4, 101-112.

http://www.researchgate.net/journal/1538-8514_Molecular_Cancer_Therapeutics

[67] Kindt, T.J., Goldsby, R.A. and Osborne, B.A. (2007) Kuby Immunology. W. H. Freeman and Co., New York.

[68] Lankat-Buttgereit, B. and Tampé, R. (1999) The Transporter Associated with Antigen Processing TAP: Structure and Function. FEBS Letters, 464, 108-112. http://www.journals.elsevier.com/febs-letters/ http://dx.doi.org/10.1016/S0014-5793(99)01676-2

[69] Groettrup, M., van den Broek, M., Schwartz, K., Macagno, A., Khan, S., de Giuli, R. and Schmidtke, G. (2001) Structural Plasticity of the Proteasome and Its Function in Antigen Processing. Critical Reviews in Immunology, 21, 339-358. http://en.wikipedia.org/wiki/Critical_Reviews_in_Immunology

[70] Niedermann, G. (2002) Immunological Functions of the Proteasome. Current Topics in Microbiology and Immunology, 268, 91-136. http://www.springer.com/series/82?detailsPage=titles http://dx.doi.org/10.1007/978-3-642-59414-4_5

[71] Rodríguez, J.A., Galeano, L., Palacios, D.M., Gómez, C., Serrano, M.L., Bravo, M.M. and Combita, A.L. (2012) Altered HLA Class I and HLA-G Expression Is Associated with IL-10 Expression in Patients with Cervical Cancer. Pathobiology, 79, 72-83. http://www.karger.com/Journal/Home/224272 http://dx.doi.org/10.1159/000334089

[72] Stupp, R., Hegi, M. and Weller, M. (2010) Neuro-Oncology, a Decade of Temozolomide and beyond. Expert Review of Anticancer Therapy, 10, 1675-1677. http://www.expert-reviews.com/loi/era http://dx.doi.org/10.1586/era.10.161

[73] Wen, P.Y., Yung, W.K., Lamborn, K.R., Dahia, P.L., Wang, Y., Peng, B., Abrey, L.E., Raizer, J., Cloughesy, T.F., Fink, K., Gilbert, M., Chang, S., Junck, L., Schiff, D., Lieberman, F., Fine, H.A. and Prados, M.D. (2006) Phase I/II Study of Imatinib Mesylate for Recurrent Malignant Gliomas: North American Brain Tumor Consortium Study 99-08. Clinical Cancer Research, 12, 4899-4907. http://www.researchgate.net/journal/1078-0432_Clinical_Cancer_Research http://dx.doi.org/10.1158/1078-0432.CCR-06-0773

[74] Pan, Q., Chanthery, Y., Liang, W.C., Stawicki, S., Mak, J., Rathore, N., et al. (2007) Blocking Neuropilin-1 Function Has an Additive Effect with Anti-VEGF to Inhibit Tumor Growth. Cancer Cell, 11, 53-67.

http://www.journals.elsevier.com/cancer-cell/ http://dx.doi.org/10.1016/j.ccr.2006.10.018

[75] Piwecka, M., Rolle, K., Wyszko, E., Żukiel, R., Nowak, S., Barciszewska, M.Z. and Barciszewski, J. (2011) Nucleic Acid-Based Technologies in Therapy of Malignant Gliomas. Current Pharmaceutical Biotechnology, 12, 1805-1822. http://benthamscience.com/journal/index.php?journalID $=\mathrm{cpb}$ http://dx.doi.org/10.2174/138920111798377067

[76] Kjaergaard, J., Wang, L.X., Kuriyama, H., Shu, S. and Plautz, G.E. (2005) Active Immunotherapy for Advanced in Tracranialmurine Tumors by Using Dendritic Cell-Tumor Cell Fusion Vaccines. Journal of Neurosurgery, 103, 156164. http://thejns.org/ http://dx.doi.org/10.3171/jns.2005.103.1.0156

[77] Reardon, D.A., Quinn, J.A., Vredenburgh, J.J., Gururangan, S., Friedman, A.H., Desjardins, A., Sathornsumetee, S., Herndon II, J.E., Dowell, J.M., McLendon, R.E., Provenzale, J.M., Sampson, J.H., Smith, R.P., Swaisland, A.J., Ochs, J.S., Lyons, P., Tourt-Uhlig, S., Bigner, D.D., Friedman, H.S. and Rich, J.N. (2006) Phase 1 Trial of Gefitinib plus Sirolimus in Adults with Recurrent Malignant Glioma. Clinical Cancer Research, 12, 860-868.

http://clincancerres.aacrjournals.org/ 
http://dx.doi.org/10.1158/1078-0432.CCR-05-2215

[78] Cavazzana-Calvo, M., Hacein-Bey-Abina, S. and Fischer, A. (2010) Ten Years of Gene Therapy: Thoughts and Perspectives. Medecine Science (Paris), 26, 115-118. http://www.medecinesciences.org/ http://dx.doi.org/10.1051/medsci/2010262115

[79] Hegi, M.E., Diserens, A.C., Gorlia, T., Hamou, M.F., de Tribolet, N., Weller, M., Kros, J.M., Hainfellner, J.A., Mason, W., Mariani, L., Bromberg, J.E., Hau, P., Mirimanoff, R.O., Cairncross, J.G., Janzer, R.C. and Stupp, R. (2005) MGMT Gene Silencing and Benefit from Temozolomide in Glioblastoma. The New England Journal of Medicine, 352, 9971003. http://www.nejm.org/ http://dx.doi.org/10.1056/NEJMoa043331

[80] Gorlia, T., van den Bent, M.J., Hegi, M.E., Mirimanoff, R.O., Weller, M., Cairncross, J.G., Eisenhauer, E., Belanger, K., Brandes, A.A., Allgeier, A., Lacombe, D. and Stupp, R. (2008) Nomograms for Predicting Survival of Patients with Newly Diagnosed Glioblastoma: Prognostic Factor Analysis of EORTC and NCIC Trial 26981-22981/CE.3. The Lancet Oncology, 9, 29-38. http://www.thelancet.com/journals/lanonc/ http://dx.doi.org/10.1016/S1470-2045(07)70384-4

[81] Stupp, R. and Hottinger, A.F. (2008) Management of Malignant Glioma-Quo Vadis? Onkologie, 31, $300-302$. http://www.karger.com/Journal/Home/261189 http://dx.doi.org/10.1159/000134024

[82] Fakhrai, H., Mantil, J.C., Liu, L., Nicholson, G.L., Murphy-Satter, C.S., Ruppert, J. and Shawler, D.L. (2006) Phase I Clinical Trial of a T5GF-Beta Antisense-Modified Tumor Cell Vaccine in Patients with Advanced Glioma. Cancer Gene Therapy, 13, 1052-1060. http://www.nature.com/cgt/index.html http://dx.doi.org/10.1038/sj.cgt.7700975

[83] Abele, R. and Tampe, R. (2006) Modulation of the Antigen Transport Machinery TAP by Friends and Enemies. FEBS Letters, 580, 1156-1163. http://www.febsletters.org/ http://dx.doi.org/10.1016/j.febslet.2005.11.048

[84] Townsend, S.E. and Allison, J.A. (1993) Tumor Rejection after Direct Costimulation of CD8 ${ }^{+}$T Cells by Transfected Melanoma Cells. Science, 259, 368-370. http://www.sciencedirect.com/ http://dx.doi.org/10.1126/science.7678351

[85] Labropoulos, S.V. and Razis, E.D. (2007) Imatinib in the Treatment of Dermatofibrosarcoma Protuberans. Biologics, 1, 347-353.

[86] Benimetskaya, L. and Stein, C.A. (2002) Antisense Therapy: Recent Advances and Relevance to Prostate Cancer. Clinical Prostate Cancer, 1, 20-30. http://www.sciencedirect.com/science/journal/15400352

[87] Jansen, B., Wacheck, V., Heere-Ress, E., Schlagbauer-Wadl, H., Hoeller, C., Lucas, T., Hoermann, M., Hollenstein, U., Wolff, K. and Pehamberger, H. (2000) Chemosensitization of Malignant Melanoma by BCL2 Antisense Therapy. The Lancet, 356, 1728-1733. http://www.thelancet.com/ http://dx.doi.org/10.1016/S0140-6736(00)03207-4

[88] Zangemeister-Wittke, U. (2003) Antisense to Apoptosis Inhibitors Facilitates Chemotherapy and TRAIL-Induced Death Signaling. Annals of the New York Academy of Science, 1002, 90-94. http://onlinelibrary.wiley.com/journal/10.1111/(ISSN)1749-6632/issues http://dx.doi.org/10.1196/annals.1281.019

[89] Tang, J., Flomenberg, P., Harshyne, L., Kenyon, L. and Andrews, D.W. (2005) Glioblastoma Patients Exhibit Circulating Tumor-Specific CD8 ${ }^{+}$T Cells. Clinical Cancer Research, 11, 5292-5299. http://clincancerres.aacrjournals.org/ http://dx.doi.org/10.1158/1078-0432.CCR-05-0545

[90] Rincon, O.L., Pareja, L.R., Jaramillo, S. and Aristizabal, B.H. (2007) Human Papillomavirus, Immune Response and Cervical Cancer: A Complex Relationship. Review Colombian of Obstetric and Ginecology, 58, 58-68.

[91] Lemoine, F.M., Cherai, M., Giverne, C., Dimitri, D., Rosenzwajg, M., Trebeden-Negre, H., Chaput, N., Barro, B., Thioun, N., Gattegnio, B., Selles, F., Six, A., Azar, N., Lotz, J.P., Buzyn, A., Sibony, M., Delcourt, A., Boyer, O., Herson, S., Klatzmann, D. and Lacave, R. (2009) Massive Expansion of Regulatory T-Cells Following Interleukin 2 Treatment during a Phase I-II Dendritic Cell-Based Immunotherapy of Metastatic Renal Cancer. International Journal of Oncology, 235, 569-581. http://www.spandidos-publications.com/ijo

[92] Chappert, P., Leboeuf, M., Rameau, P., Lalfer, M., Desbois, S., Liblau, R.S., Danos, O., Davoust, J.M. and Gross, D.A. (2010) Antigen-Specifictreg Impair CD8 ${ }^{+}$T-Cell Priming by Blocking Early T-Cell Expansion. European Journal of Immunology, 40, 339-350. http://onlinelibrary.wiley.com/journal/10.1002/(ISSN)1521-4141 http://dx.doi.org/10.1002/eji.200839107

[93] Le Gall, T., Loizeau, D., Picquet, E., Carmoy, N., Yaouanc, J.J., Burel-Deschamps, L., Delépine, P., Giamarchi, P., Jaffrès, P.A, Lehn, P. and Montier, T. (2010) A Novel Cationic Lipophosphoramide with Diunsaturated Lipid Chain Synthesis, Physicochemical Properties and Transfection Activities. Journal of Medicinal Chemistry, 53, 1496-1508. 
http://pubs.acs.org/journal/jmcmar http://dx.doi.org/10.1021/jm900897a

[94] Engelen, S., Trojan, L.A., Sacquin-Mora, S., Lavery, R. and Carbone, A. (2009) Joint Evolutionary Trees: A LargeScale Method to Predict Protein Interface Based on Sequence Sampling. PLoS Computational Biology, 5, Article ID: e1000267. http://www.ploscompbiol.org/ http://dx.doi.org/10.1371/journal.pcbi.1000267

[95] Mack, J.T., Brown, C.B. and Tew, K.D. (2008) ABCA2 as a Therapeutic Target in Cancer and Nervous System Disorders. Expert Opinion on Therapeutic Targets, 12, 491-450. http://informahealthcare.com/journal/ett http://dx.doi.org/10.1517/14728222.12.4.491

[96] Trojan, L.A., Wei, M.X., Jarocki, P., Glogowska, A., Ly, A., Czarny, J., Kopinski, P., Przewlocki, R., Henin, D. and Trojan, J. (2002) IGF-I: From Diagnostic to Triple-Helix Gene Therapy of Glioblastom. Acta Biochimica Polonica, 49, 979-990. http://www.actabp.pl/

[97] Adachi, Y., Yamamoto, H., Ohashi, H., Endo, T., Carbone, D.P., Imai, K. and Shinomura, Y. (2010) A Candidate Targeting Molecule of Insulin-Like Growth Factor-I Receptor for Gastrointestinal Cancers. World Journal of Gastroenterology, 16, 5779-5789. http://www.wjgnet.com/1007-9327/index.jsp http://dx.doi.org/10.3748/wjg.v16.i46.5779

[98] Moro-Sibilot, D.M., Coudurier, M. and Lantuejou, S. (2010) Targeting Insulin-Like Growth Factors in the Treatment of Cancer. Review des Maladies Respiratoires, 27, 959-963. http://www.sciencedirect.com/science/journal/07618425

[99] Sachdev, D. (2010) Targeting the Type I Insulin-Like Growth Factor System for Breast Cancer Therapy. Current Drug Targets, 11, 1121-1132. http://benthamscience.com/journal/index.php?journalID=cdt http://dx.doi.org/10.2174/138945010792006816

[100] Zumkeller, W. (2002) IGFs and IGF-Binding Proteins as Diagnostic Markers and Biological Modulators in Brain Tumours. Experimental Review of Molecular Diagnostic, 2, 473-477. http://www.expert-reviews.com/toc/erm/8/3

[101] Wu, Y., Yakar, S., Henninghausen, L. and Le Roith, D. (2002) Circulating Insulin-Like Growth Factor-I Levels Regulatecolon Cancer Growth and Metastasis. Cancer Research, 62, 1030-1035. http://cancerres.aacrjournals.org/

[102] Dietrich, P.Y., Dutoit, V., Tran Thang, N.N. and Walker, P.R. (2010) T-Cell Immunotherapy for Malignant Glioma: Toward a Combined Approach. Current Opinion in Oncology, 22, 604-610. http://journals.lww.com/co-oncology/pages/default.aspx http://dx.doi.org/10.1097/CCO.0b013e32833dead8

[103] Iwami, K., Natsume, A. and Wakabayashi, T. (2010) Gene Therapy for High-Grade Glioma. Neurologia Medico, Chirurgica (Tokyo), 50, 727-736. http://jams.med.or.jp/journal_list/047_78e.html

[104] Le Corre, S.S., Berchel, M., Belmadi, N., Denis, C., Haelters, J.P., Le Gall, T., Lehn, P., Montier, T. and Jaffrès, P.A. (2014) Cationic Lipophosforamidates with Two Different Lipid Chains: Synthesis and Evaluation as Gene Carriers. Organic \& Biomolecular Chemistry, 12, 1463-1474. http://pubs.rsc.org/en/journals/journalissues/ob\#!recentarticles\&all http://dx.doi.org/10.1039/c3ob42270d 